Volume 6 | Issue 2

3-2019

\title{
Managing Hurricane (And Other Natural Disaster) Risk
}

Robert Jerry II

University of Missouri School of Law, jerryr@missouri.edu

Follow this and additional works at: https://scholarship.law.tamu.edu/lawreview

Part of the Disaster Law Commons, Environmental Law Commons, and the Water Law Commons

\section{Recommended Citation}

Robert Jerry II, Managing Hurricane (And Other Natural Disaster) Risk, 6 Tex. A\&M L. Rev. 391 (2019). Available at: https://doi.org/10.37419/LR.V6.I2.3

This Article is brought to you for free and open access by Texas A\&M Law Scholarship. It has been accepted for inclusion in Texas A\&M Law Review by an authorized editor of Texas A\&M Law Scholarship. For more information, please contact aretteen@law.tamu.edu. 


\title{
MANAGING HURRICANE (AND OTHER NATURAL DISASTER) RISK
}

\author{
by: Robert H. Jerry, II*
}

TABLE OF CONTENTS

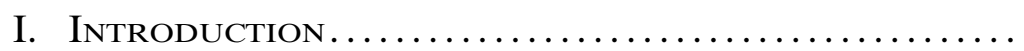

II. The Elements of Natural Disaster Risk Management and Recovery................... 402

A. The Current "National Preparedness" Framework .. 402

B. Insurance and the National Preparedness

Framework................................... 407

1. Recovery, Prevention, and Mitigation ........ 407

2. Ex Ante Risk Management and Ex Post

Damage Relief............................ 411

3. Private Versus Public Risk Management....... 412

C. The Natural Disaster Risk Management-Recovery

Matrix .................................

III. Hurricanes, the Matrix, And Natural Disaster

Mismanagement............................. 415

A. Underinvestment in Prevention ................. 416

B. Limitations of Private Insurance ................ 427

C. Ineffective Government Intervention to Support

Private Insurance Markets.................... 433

D. Incomplete and Mismatched Disaster Relief ........ 439

IV. The Natural Disaster Risk Management

Future ...................................

\section{INTRODUCTION}

No one living in a coastal county in Texas should need to be told that hurricanes are dangerous. ${ }^{1}$ From the 1900 Galveston hurricane, ${ }^{2}$

* Isidor Loeb Professor, University of Missouri School of Law. This Article is based on comments I made at a symposium, titled "Natural Disasters, Stakeholder Engagement and Dispute Resolution," held at the Texas A\&M University School of Law, Fort Worth, Texas, on April 13, 2018. I express my deep appreciation to the following for their generous support during my work on this project: the Lawrence G. Crahan \& Linda S. Legg Faculty Research Fellowship; the Edgar Mayfield Faculty Research Fellowship; and the Charles H. Rehm Faculty Research Fellowship. I also thank Matthew Neuman, Missouri Law '19, for his superb research assistance, and the Shook, Hardy \& Bacon law firm, which provided funding for Matthew's work through the Shook, Hardy \& Bacon Research Assistant Program.

1. An alarming number of people disregard hurricane warnings and evacuation orders at great personal peril. See, e.g., Linda I. Gibbs \& Caswell F. Holloway, Hurricane Sandy After Action: Report and Recommendations to Mayor Michael R. BloOMberg 8-10 (2013), available at http://www.nyscal.org/files/2013/ 06/Hurricane-Sandy-After-Action-May-20131.pdf (explaining that "thousands of people did not leave the evacuation zone" after Mayor Bloomberg issued a mandatory DOI: https://doi.org/10.37419/LR.V6.I2.3 
which produced the largest number of fatalities of any natural disaster event in U.S. history, ${ }^{3}$ to Hurricane Harvey in $2017,{ }^{4}$ which may rank as the second-most costly catastrophe in our nation's history, ${ }^{5}$ Texans have endured some of the costliest natural disasters to ever inflict havoc in the U.S.

If the second-most populous state in the nation were the only state to endure such calamities, there would be great reason for concern. ${ }^{6}$ Texas, however, is not alone. The hurricane risk presents itself along the entire U.S. coastline from Cutler, Maine to Brownsville, Texas.

evacuation during Hurricane Sandy, and forty-three New Yorkers died). Warnings go unheeded for a variety of reasons, including personal perception of risk, evacuation logistics, past storm experience, confusion surrounding official warnings, and an unwillingness to separate from pets. Gregg C. Bowser \& Susan L. Cutter, Stay or Go: Examining Decision Making and Behavior in Hurricane Evacuations, 57 Env'T 28, 30-38 (2015). Thus, repeated reminders to the public of the dangers of hurricanes are important.

2. See generally Erik Larson, IsaAc's Storm: A Man, a Time, and the Deadliest Hurricane in History (1999) (recounting the damage of an unanticipated hurricane).

3. The death toll from the Galveston hurricane is unknown, but estimates put the number at approximately 12,000. Christopher Ingraham, Hurricane Maria Was One of the Deadliest Natural Disasters in U.S. History, According to a New Estimate, WAsH. Post (June 2, 2018), https://www.washingtonpost.com/news/wonk/wp/2018/06/02/hur ricane-maria-was-one-of-the-deadliest-natural-disasters-in-u-s-history-according-to-anew-estimate [https://perma.cc/2LUL-CT3G] (Galveston hurricane death toll of 12,000 exceeds recent estimate of Hurricane Maria's death toll of 4,645). Estimates of the death toll in Hurricane Maria have risen since the storm. After initially putting the number of deaths at sixty-four, in August 2018 the government of Puerto Rico endorsed a recent analysis of the death toll estimating that 2,975 people died as a result of the disaster and its effects. See Sheri Fink, Nearly a Year After Hurricane Maria, Puerto Rico Revises Death Toll to 2,975, N.Y. Times (Aug. 28, 2018), https://www.ny times.com/2018/08/28/us/puerto-rico-hurricane-maria-deaths.html [https://perma.cc/ 8SMK-CWBC].

4. Hurricane Harvey struck the Texas coast as a Category 4 hurricane, but its extreme impact came when "[t]he storm then stalled, with its center over or near the Texas coast for four days, dropping historic amounts of rainfall of more than 60 inches over southeastern Texas." Eric S. Blake \& David A. Zelinsky, Hurricane HarVEY, NAT'L HurRicANe CTR. 1 (2018), available at https://www.nhc.noaa.gov/data/ tcr/AL092017_Harvey.pdf. The storm was also deadly with at least sixty-eight direct deaths and thirty-five indirect deaths. $I d$. at 8.

5. Billion-Dollar Weather and Climate Disasters: Table of Events, NAT'L CTRs. FOR ENVTL. INFO., https://www.ncdc.noaa.gov/billions/events/US/1980-2018 (last visited Aug. 31, 2018) [https://perma.cc/6BCU-FHTC]. As of August 2018, Hurricane Harvey's CPI-adjusted cost was $\$ 127.5$ billion, behind only Hurricane Katrina at $\$ 165.0$ billion. Id. But see Facts + Statistics: Hurricanes, Ins. Info. Inst., https:// www.iii.org/fact-statistic/facts-statistics-hurricanes (last visited Dec. 12, 2018) [https:// perma.cc/7XDV-L7MD] (indicating that when loss estimates become final, Harvey's total costs will range between $\$ 50$ and $\$ 72$ billion, making Harvey the sixth-costliest hurricane on record).

6. The three most populous states are California, Texas, and Florida. U.S. and World Population Clock, U.S. Census Bureau, https://www.census.gov/popclock/ (last visited June 22, 2018) [https://perma.cc/29Q6-M9ZB]. Each state is subject to significant natural disaster risk.

7. See Ian Livingston, The Regions Most At-Risk for Atlantic Hurricanes in 3 Maps, WAsh. Post (Sept. 14, 2015), https://www.washingtonpost.com/news/capital- 
This risk is not best measured by miles; this run of coast is the land area in the U.S. that has the largest population ${ }^{8}$ and property densities. ${ }^{9}$ Florida has the most exposure because $79 \%$ of Florida's total insured property is on the coasts, ${ }^{10}$ but New York and Texas have high exposures, too. ${ }^{11}$ Compounding the concern is that the risk of hurricane damage is increasing and shows no signs of abating. A growing consensus exists among scientists that warmer oceans increase the amount of water vapor entering the atmosphere, which, although it may not increase the number of hurricanes, increases the intensity of those that form. ${ }^{12}$ In addition, melting glaciers and polar ice caps are

weather-gang/wp/2015/09/14/the-regions-most-at-risk-for-atlantic-hurricanes-in-3maps/?utm_term=.d09f5e47a012 [https://perma.cc/H8US-B73P]. Hurricanes typically weaken into tropical storms by the time they reach the colder waters of New England, but storms of this intensity can cause immense damage. EdwARD AgUAdo \& JAMES E. Burt, Understanding Weather and Climate 364-65 (4th ed. 2007). The Great Hurricane of 1938 stands as the most devastating recorded hurricane; it caused extensive damage in Long Island and Connecticut. See Aimee Tucker, Worst Hurricanes in New England History, New England Today (Feb. 26, 2018), https://newengland.com/today/living/new-england-history/worst-hurricanes-in-new-england-history/ [https://perma.cc/2BFD-4SJ9]. If the 1938 hurricane were to repeat itself today, it would be a catastrophe of enormous proportions, probably the worst in economic terms in the history of our planet. See John Rather, Dreading A Replay of the 1938 Hurricane, N.Y. Times (Aug. 28, 2005), https://www.nytimes.com/2005/08/28/nyregion/ nyregionspecial2/dreading-a-replay-of-the-1938-hurricane.html [https://perma.cc/ Y4ZE-5KP3]. See Hurricane Preparedness, Rio Grande Valley: Hurricane History, NAT'L WeATHer SeRv., https://www.weather.gov/bro/hurrprep_history (last visited June 22, 2018) [https://perma.cc/CA53-ZRGY] (detailing nine notable storms, including Hurricane Dolly (2008), Hurricane Ike (2008), and Hurricane Alex (2010)).

8. Kristen Crossett et al., Nat'l Oceanic and Atmospheric Admin., Population Trends Along the Coastal United States: 1980-2008 7, 14, 18, 20 (2004), available at https://aamboceanservice.blob.core.windows.net/oceanserviceprod/programs/mb/pdfs/coastal_pop_trends_complete.pdf. In 2003, the national average population density was ninety-eight persons per square mile. $I d$. at 7 . The population densities of the Gulf of Mexico, Southeast, and Northeast coastal counties were 164, 224, and 641 persons per square mile, respectively. Id. at 14, 18, 20.

9. See Ashley C. Freeman \& Walker S. Ashley, Changes in the U.S. Hurricane Disaster Landscape: The Relationship Between Risk and Exposure, 88 NAT. HAzARds 659, 663-67 (2017) (analyzing housing unit data within 50-kilometer increments from the coast and concluding that "[housing unit] density and subsequent growth in that density near the coastline is aligning more people and their property with the risks from tropical cyclone hazards-including hurricane induced storm surge and winds which could cause more frequent and higher magnitude disasters in the future").

10. Tim Doggett, The Growing Value of U.S. Coastal Property at Risk, AIR (Apr. 23, 2015), http://www.air-worldwide.com/Publications/AIR-Currents/2015/The-Grow ing-Value-of-U-S-Coastal-Property-at-Risk/ [https://perma.cc/PBA7-NCCP].

11. Id. (noting the percentage of insured value in coastal counties in the states of New York and Texas as $62 \%$ and $26 \%$, respectively). The total value of coastal property in New York is $\$ 2.92$ trillion, and the numbers for Florida and Texas (the second and third largest by number on the Gulf and East Coasts) are $\$ 2.86$ trillion and $\$ 1.18$ trillion, respectively. $I d$.

12. Kevin E. Trenberth et al., Hurricane Harvey Links to Ocean Heat Content and Climate Change Adaptation, 6 EARTH's Future 730, 739 (2018) (citing research and concluding that "a warming ocean will facilitate more [tropical cyclone] activity and more rainfall and flooding"). Post-Harvey research on the extent to which that hurricane's record rainfall is attributable to global warming has set the percentage, de- 
causing sea levels to rise, ${ }^{13}$ which leads to more severe coastal flooding when intense storms make landfall. ${ }^{14}$ As the storm risk increases, human behavior is adding to the exposure. One provider of catastrophe risk-modeling software and consulting services predicts that total values insured will double every decade in U.S. coastal areas due to growing residential and commercial density and increasing construction expenses. ${ }^{15}$

pending on the study, in a range of roughly $15-40 \%$. If the number were $35 \%$, this would mean that climate change increased Harvey's rainfall totals by roughly 15 inches, an increase that led to enormous additional devastation. Id. Whether ocean warming increases the number of hurricanes that form is less well understood, but the link between ocean warming and intensity is clear: "We thus expect [tropical cyclone] intensities to increase with warming, both on average and at the high end of the scale, so that the strongest future storms will exceed the strength of any in the past." Sobel et al., Human Influence on Tropical Cyclone Intensity, 353 ScI. 242, 242 (2016). Water vapor is the fuel for hurricanes. Alan P. Trujillo \& Harold V. Thurman, EssenTIALS OF OCEANOGRAPHY 185 (8th ed. 2005) ("Tropical cyclones begin as low-pressure cells that break away from the equatorial low-pressure belt and grow as they pick up heat and energy for the warm ocean. Surface winds feed moisture (in the form of water vapor) into the storm. When water evaporates, it stores tremendous amounts of latent heat of evaporation, which is released as latent heat of condensation when the water vapor condenses to form liquid water (rain). The release of vast amounts of water's latent heat of condensation powers tropical cyclones.").

13. See, e.g., Arctic Monitoring \& Assessment Programme, Snow, Water, Ice and Permafrost in the Arctic: Summary for Policy-Makers 4 (2017), available at https://www.amap.no/documents/doc/Snow-Water-Ice-and-Permafrost.Summary-for-Policy-makers/1532 ("The loss of land-based ice has accelerated in recent decades. Since at least 1972, the Arctic has been the dominant source of global sea-level rise. [70\%] of the Arctic's contribution to sea-level rise comes from Greenland, which on average lost 375 gigatons of ice per year-equivalent to a block of ice measuring 7.5 kilometers or 4.6 miles on all sides-from 2011 to 2014."). See generally Sea Level Rise Viewer, OfFice for CoAstal Mgmt., https://coast.noaa.gov/digitalcoast/tools/slr.html (last visited June 25, 2018) [https://perma.cc/HH3M-A4WP] (depicting sea level rise scenarios for U.S. coastal locations).

14. Mir Emad Mousavi et al., Global Warming and Hurricanes: The Potential Impact of Hurricane Intensification and Sea Level Rise on Coastal Flooding, 104 CLIMATIC Change 575, 577-78 (2011). Coupled with coastline subsidence, the problem is further exacerbated. See, e.g., Daniel Glick, The Big Thaw, NAT'L GeOgraphic, https://www.nationalgeographic.com/environment/global-warming/big-thaw/ (last visited June 25, 2018) [https://perma.cc/Y3K6-36PM] ("In southern Louisiana, coasts are literally sinking by about three feet (a meter) a century, a process called subsidence. A sinking coastline and a rising ocean combine to yield powerful effects. It's like taking the global sea-level-rise problem and moving it along at fast-forward.").

15. AIR, The Coastline at Risk: 2013 Update to the Estimated Insured Value of U.S. Coastal Properties 3 (2013), available at https://www.air-worldwide.com/publications/white-papers/documents/the-coastline-at-risk-2013. A case-inpoint is the 1926 Great Miami Hurricane that crossed southern Florida, entered the Gulf, and then made landfall again in Pensacola before crossing coastal Mississippi and Louisiana. See Great Miami Hurricane of 1926, Nat'L Weather Serv., https:// www.weather.gov/mfl/miami_hurricane (last visited June 25, 2018) [https://perma.cc/ 2AXG-4FA7]. At the time, the City of Miami and the surrounding area were developing rapidly, and despite the fact that the city had a Weather Bureau Office, little advance warning was given to a population largely unaccustomed to such storms; 372 people died. Id. If the 1928 hurricane were to repeat itself today, economic losses would be approximately $\$ 140-157$ billion, larger than any hurricane disaster to date. 
When discussing risk, numeracy is important, and small sample sizes - both in numbers and years - are problematic. But it is impossible to look at changes in the lists of the costliest catastrophes over the past decade and fail to conclude that a major problem confronts us. As of 2018, of the ten largest catastrophes in U.S. history in terms of insured losses, eight were hurricanes, seven had occurred since $2000,{ }^{16}$ and three of them, all among the six largest, occurred in $2017 .{ }^{17}$ If

Roger A. Pielke et al., Normalized Hurricane Damage in the United States: 1900-2005, 9 Nat. Hazards Rev. 29, 35 (normalizing damage to 2005 conditions).

16. See Facts + Statistics: U.S. Catastrophes, Ins. Info. Inst., https://www.iii.org/ fact-statistic/facts-statistics-us-catastrophes (last updated Dec. 7, 2018) [https:// perma.cc/N6KM-D3EL] (listing seven post-2000 hurricanes-Katrina 2005; Maria 2017; Irma 2017; Sandy 2012; Harvey 2017; Ike 2008; Wilma 2005; the pre-2000 hurricane on the list is Andrew 1992; the remaining two are the 9/11/01 attacks and the 1994 Northridge, California earthquake).

17. See Billion-Dollar Weather, supra note 5 (listing, in order, in CPA-adjusted dollars, Katrina 2005, \$165.0 billion; Harvey 2017, \$127.5 billion; Maria 2017, $\$ 91.8$ billion; Sandy 2012, \$72.2 billion; Irma 2017, $\$ 51.0$ billion). But see Facts + Statistics: U.S. Catastrophes, supra note 16 (indicating that when estimates become final, Maria will be the second-costliest hurricane in U.S. history, Irma will be the fourth, and Harvey will be the sixth). Moody's estimates that total economic losses were Harvey, $\$ 133.5$ billion; Maria, $\$ 120$ billion; and Irma, $\$ 84.2$ billion. See Leslie Scism \& Erin Ailworth, Moody's Pegs Florence's Economic Cost at $\$ 38$ Billion to $\$ 50$ Billion, W ALL ST. J. (Sept. 21, 2018), https://www.wsj.com/articles/moodys-pegs-florences-economiccost-at-38-billion-to-50-billion-1537572161 [https://perma.cc/7K3B-K94L]. When loss figures are finalized for the 2018 season, Hurricanes Florence and Michael may be intermingled on this the foregoing list. See id. Before Hurricane Andrew, which made landfall near Homestead, Florida in 1992, the most damaging hurricane in U.S. history was Hurricane Hugo, which made landfall north of Charleston, South Carolina in 1989 and caused what would in 2017 be \$14 billion of damage. See CostLIEST U.S. Tropical Cyclone Tables Updated, Nat'l Hurricane Ctr. (2018) [hereinafter COSTLIEST TABLE], available at https://www.nhc.noaa.gov/news/UpdatedCostliest.pdf; Hurricane Hugo, Nat'l Weather Serv., https://www.weather.gov/ilm/hurricanehu go (last updated Sept. 21, 2014) [https://perma.cc/U65W-KKKL]; Hurricanes in History, NAT'L HurRICANE CTR., https://www.nhc.noaa.gov/outreach/history/ (last visited June 26, 2018) [https://perma.cc/AUW8-ZYUW]. Pre-Andrew experts thought that the maximum damage that could be caused by a hurricane was about $\$ 14$ billion (in current dollars). Hurricane Andrew was transformational in that it was the first major hurricane to hit a highly-developed coastline and, with $\$ 47.8$ billion in total cost (in current dollars), was the costliest natural disaster in U.S. history at the time. See Costliest TABle, supra. More shocking is that the eye of Andrew was a glancing blow for Miami, which would have produced losses roughly four times those actually incurred if it had been a direct hit on downtown Miami. Ryan Yousefi, 100-Year Hurricane Could Cost \$250 Billion if It Hit Miami, Miami New Times (Apr. 16, 2015), http://www.miaminewtimes.com/news/100-year-hurricane-could-cost-250-billion-if-ithit-miami-7572520 [https://perma.cc/8ERA-4AM2] ("In 1992, Andrew made landfall south of Miami near Homestead, the final bill to fix the damages ended up being around $\$ 15$ billion in insured losses but, had Andrew struck just 50 miles north of Homestead, the losses would have been four-times that, or nearly $\$ 60$ billion at the time."). With the new understanding taught by Andrew, experts began modeling the next "big one" without thinking about the possibility of a series of smaller hurricanes hitting in quick succession. See Patricia Jones Kershaw \& Byron Mason, Lessons Learned Between Hurricanes: From Hugo to Charley, Frances, Ivan, AND JEANNE 5-6 (2005), available at https://www.nap.edu/read/11528/chapter/2\#5 ("Floridians experienced . . . 'hurricane fatigue[,]'" and state resources were over- 
measured in terms of insured losses, Hurricane Harvey will rank as the sixth costliest disaster in U.S. history, which understates the total destruction of this storm because it presented as a flood event rather than a wind event. ${ }^{18}$ Only $20 \%$ of properties that suffered flood damage during Harvey were insured. ${ }^{19}$ In terms of total economic lossesinsured and uninsured-Harvey rivals the losses caused by Hurricane Katrina in 2005, which is likely to remain the costliest catastrophe in U.S. history, at least until the next hurricane season is over. Two hurricanes in the 2018 season-Florence and Michael-were so severe that they may reorder these lists, which only underscores the enormity of the problem squarely in our midst. ${ }^{20}$

If one adds the Pacific coastal counties, which have a tsunami exposure due to the earthquake risk in that area, ${ }^{21}$ to the counties on the

whelmed after being stretched thin for so long responding to the four smaller hurricanes). In 2004 and 2005, eight hurricanes-Charley, Frances, Ivan, Jeanne, Dennis, Katrina, Rita, and Wilma-hit Florida. While none was nearly as strong as Andrew, their cumulative impact was greater than Andrew's. See CostLIEst TABLE, supra. By one calculation, one out of every five homes in Florida suffered some damage in at least one of the eight hurricanes. Tom Gallagher, We Must Improve Property Insurance Options, Tallahassee Democrat (Apr. 16, 2006), https://www.myfloridacfo. com/pressoffice/Newsletter/2006/041706/April_1706ALT2.htm [https://perma.cc/522STQRP].

18. As of August 2018, overall insurers have paid more than $\$ 19$ billion for Harvey-related claims. 13th Annual Hurricane Tour Returns to Texas Coast, Ins. CouncIL TeX. (Aug.17, 2018) https://www.insurancecouncil.org/4DCGI/cms/review.html?Ac tion=CMS_Document\&DocID=639\&MenuKey=123[https://perma.cc/7MF4-RU6T]. The number may rise to the vicinity of $\$ 30$ billion. See RMS Estimates Hurricane Harvey Insured Losses From Wind, Storm Surge and Inland Flood Damage Will Be Between USD \$25 and \$35 Billion, RMS, https://www.rms.com/newsroom/press-re leases/press-detail/2017-09-09/rms-estimates-hurricane-harvey-insured-losses-fromwind-storm-surge-and-inland-flood-damage-will-be-between-usd-25-and-35-billion (last visited June 26, 2018) [https://perma.cc/M9LN-6VUY].

19. Heather Long, Where Harvey Is Hitting Hardest, 80 Percent Lack Flood Insurance, WAsH. Post (Aug. 29, 2017), https://www.washingtonpost.com/news/wonk/wp/ 2017/08/29/where-harvey-is-hitting-hardest-four-out-of-five-homeowners-lack-floodinsurance/?utm_term=.9883283e5527 [https://perma.cc/DA7T-9R5D] ("Only 17[\%] of homeowners in the eight counties most directly affected by Harvey have flood insurance policies, according to a Washington Post analysis of Federal Emergency Management Agency data.").

20. One estimate puts Hurricane Florence's economic cost at $\$ 38-50$ billion. See Scism \& Ailworth, supra note 17. Although Hurricane Michael was the most powerful hurricane to strike the U.S. since Hurricane Andrew in 1992, because it hit an area of the Florida panhandle relatively less-populated and less-developed than most of the Gulf Coast, economic losses, though severe, will be less than other storms. One estimate places Michael's economic losses at \$25 billion. See Brian K. Sullivan \& Katherine Chiglinsky, Hurricane Michael's Cost: $\$ 25 B$ With up to $\$ 8 B$ in Insured Losses, Claims J. (Oct. 12, 2018), https://www.claimsjournal.com/news/southeast/2018/10/12/ 287298.htm [https://perma.cc/H3SE-JF5Y]. Insured losses in both storms, as with Harvey, may not be especially severe because most of the economic loss was uninsured flood loss.

21. See Paula K. Dunbar \& Craig S. Weaver, Nat'l Tsunami Hazard Mitigation Program, United States and Territories National Tsunami Hazard Assessment: Historical Record And Sources for Waves - Update 2, available at https://nws.weather.gov/nthmp/documents/Tsunami_Assessment_2016Update.pdf 
Maine-Texas coastline, 123.3 million people, according to the 2010 census, which constitutes $39 \%$ of the nation's population, live in highrisk coastal counties. ${ }^{22}$ This number is expected to increase by eleven million in the 2020 census. $^{23}$ Because people have demonstrated an affinity for occupying land on or near the coasts, this population growth will almost certainly increase the amount and values of property at risk along the coasts as well.

If hurricanes were the only major disaster hazard in the country, we would have plenty of reason for grave concern, but that is not the situation. ${ }^{24}$ Global climate change, which adds teeth to hurricanes, has significant implications for non-coastal areas as well. When increased atmospheric humidity combines with increased temperatures over land and a reduced average temperature differential between the earth's poles and the equator, more precipitation falls in single large storms instead of in a series of smaller storms, which leads to increasingly intense cycles of droughts and floods. ${ }^{25}$ Different areas of the

(noting tsunami hazard for different U.S. regions by reference to historical record and earthquake probabilities); Robert W. Christopherson, Geosystems 511 (6th ed. 2006) ("A warning system . . . is in operation for nations surrounding the Pacific, where the majority of tsunamis occur. A warning is issued whenever seismic stations detect a significant quake or landslide under water, where it might generate a tsunami."). A hurricane landfall in southern California is possible, but highly unlikely; the only known hurricane to make landfall in California occurred in San Diego in 1858. See Sean Breslin, What's the Likelihood of a Hurricane Hitting California?, Weather Channel (July 21, 2015), https://weather.com/storms/hurricane/news/cali fornia-hurricane-chances [https://perma.cc/NG2N-PDEV]. The cold waters of the Pacific almost always prevent hurricanes from maintaining intensity all the way to the West Coast and make it virtually impossible to sustain strength north of southern California. Id. But these tropical systems can still be intense and cause widespread destruction along the coast.

22. NOAA, National Coastal Population Report: Population Trends FROM 1970 TO 2020 (Mar. 2013), available at https://aamboceanservice.blob.core.wind ows.net/oceanservice-prod/facts/coastal-population-report.pdf [https://perma.cc/ B54A-TFGZ].

23. $I d$.

24. The Robert T. Stafford Disaster Relief and Emergency Assistance Act, 42 U.S.C. $\$ 5121$ et seq. (2018), defines "major disaster" as any devastating emergency resulting from a natural calamity or an accidental or man-caused event. 42 U.S.C. $\S 5122(2)$ (2018) ("'Major disaster' means any natural catastrophe (including any hurricane, tornado, storm, high water, wind-driven water, tidal wave, tsunami, earthquake, volcanic eruption, landslide, mudslide, snowstorm, or drought), or, regardless of cause, any fire, flood, or explosion, in any part of the United States, which in the determination of the President causes damage of sufficient severity and magnitude to warrant major disaster assistance under this chapter to supplement the efforts and available resources of States, local governments, and disaster relief organizations in alleviating the damage, loss, hardship, or suffering caused thereby."). The Post-Katrina Emergency Management Reform Act of 2006 adopts the same definition. 6 U.S.C. § 701(6) (2018).

25. See the Impact of Climate Change on Natural Disasters, Earth ObservaTORY, NASA, https://earthobservatory.nasa.gov/Features/RisingCost/rising_cost5.php (last visited June 27, 2018) [https://perma.cc/W7RD-VUYS]. 
country also face the risk of tsunamis, ${ }^{26}$ non-hurricane-induced flooding, ${ }^{27}$ landslides,${ }^{28}$ earthquakes,${ }^{29}$ wildfires,${ }^{30}$ volcanoes,${ }^{31}$ tornadoes,${ }^{32}$

26. See Paula K. Dunbar \& Craig S. Weaver, Nat'l Tsunami Hazard Mitigation Program, United States and Territories National Tsunami Hazard Assessment: Historical Record and Sources for Waves - Update 2, https:// nws.weather.gov/nthmp/documents/Tsunami_Assessment_2016Update.pdf [https:// perma.cc/E69Q-P32T] (noting tsunami hazard for different U.S. regions by reference to historical record and earthquake probabilities).

27. See, e.g., Tim Craig \& Angela Fritz, Immense Rains Are Causing More Flash Flooding, and Experts Say It's Getting Worse, WAsH. Post (June 24, 2018), https:// www.washingtonpost.com/national/immense-rains-are-causing-more-flash-floodingand-experts-say-its-getting-worse/2018/06/24/ [https://perma.cc/ZNY5-KQH8] (describing increases in observed heavy precipitation events). Obviously, this is also largely a consequence of local geographic factors. See generally FEMA Flood Map Service Center: Welcome!, FEMA, https://msc.fema.gov/portal (last visited June 27, 2018) [https://perma.cc/VF34-MZPG] (displaying flood hazard information from the National Flood Insurance Program by input location).

28. See Landslide Overview Map of the Conterminous United States, USGS, https:/ /pubs.usgs.gov/pp/p1183/figures/map.jpg (last updated Dec. 1, 2016) [https://perma.cc/ N9M6-2P4N] (showing, at a coarse scale, areas susceptible to landslides). See also Which States Are Prone to Landslides-And How Can You Prepare?, NBC News (Mar. 24, 2014), https://www.nbcnews.com/storyline/deadly-mudslide/which-statesare-prone-landslides-how-can-you-prepare-n60761 [https://perma.cc/M5EW-9X8C] ("Slides can occur in all 50 states, but regions like the Appalachian Mountains, the Rocky Mountains and the Pacific Coastal Ranges have 'severe landslide problems,' according to the USGS.").

29. See Seismic Hazard Maps and Site-Specific Data, USGS, https://earthquake.usgs.gov/hazards/hazmaps/ (last visited June 27, 2018) [https://perma.cc/JR2R$7 \mathrm{BMN}$ ] (showing high hazard areas not only along the west coast of the U.S., but also in other pockets across the country). "Active seismic regions include the West Coast, the Wasatch Front of Utah northward into Canada, the Central Mississippi Valley, the southern Appalachians, and portions of South Carolina, [and] upstate New York ...." Christopherson, supra note 21, at 383.

30. See Learn More About Wildfires, NAT'L Geographic, https://www.national geographic.com/environment/natural-disasters/wildfires/ (last visited June 27, 2018) [https://perma.cc/7HSP-5KAL] (noting that "Montana, Idaho, Wyoming, Washington, Colorado, Oregon, and California experience some of the worst conflagrations in the U.S."). More than 100,000 wildfires burn four to five million acres of land in the U.S. each year. Id. See also, supra notes 27-28. Also, increased temperatures over land in some parts of the country is increasing the number of wildfires and the extent of the damage caused by them. The consensus of experts is that climate change is one of the contributing causes to the recent increase in wildfires in the western U.S. See A. L. Westerling, Warming and Earlier Spring Increase Western U.S. Forest Wildfire Activity, 313 ScI. 940, 940-41 (2006) (finding an increase in large wildfires in the western United States beginning in the 1980s associated with increased spring and summer temperatures and also a wildfire season increase of seventy-eight days, comparing 1970 to 1986 with 1987 to 2003); Chelsea Harvey, Here's What We Know About Wildfires and Climate Change, ScI. Am. (Oct. 13, 2017), https://www.scientificamerican .com/article/heres-what-we-know-about-wildfires-and-climate-change/ [https:// perma.cc/H3GJ-AGUQ] (noting that increased temperatures result in drier fuel for fires, cause an increased frequency of lightning strikes that start fires, extend the duration of the fire season, and alter wind patterns that drive fires). In recent years, the wildfire risk has taken on much greater urgency, especially in California. By midAugust 2018, the Meocino Complex fire had become the largest wildfire in California history, with eleven people killed and hundreds of thousands of acres destroyed. See California Fire Coverage, L.A. TIMEs, http://www.latimes.com/local/california/la-mecalifornia-fires-blog-htmlstory.html (last visited Dec. 10, 2018) [https://perma.cc/6F7L- 
C6J4]. Multiple variables are combining in the western states, and especially in California, to increase the frequency, intensity, and damage of wildfires. One of the most important variables is population growth, which is pushing suburban growth to the edges of forested areas. See Priya Krishnakumar \& Joe Fox, Why the 2017 Fire Season Has Been One of California's Worst, L.A. TIMEs, http://www.latimes.com/projects/lame-california-fire-seasons/ (last updated Dec. 5, 2017) [https://perma.cc/K27R-B875] (explaining that wildland-urban interface areas are high-risk because of the close proximity of housing and vegetation). See generally Roger B. Hammer et al., Demographic Trends, the Wildland-Urban Interface, and Wildfire Management, 22 Soc'y \& NAT. REs. 777 (discussing the demographic processes leading to an expansion of population in the wildland-urban interface). In these wildland-urban interfaces, emergency officials stress the importance of a "defensible space," a buffer area that guards the home from ignition due to nearby burning material, among other construction techniques and development standards. See Nat'l Fire Protection Ass'n, Community Wildfire Safety Through Regulation: A Best Practices Guide for Planners And Regulators 20-21 (2013), available at https://www.nfpa.org/-/media/ Files/Public-Education/By-topic/Wildland/WildfireBestPracticesGuide.ashx?la=EN.

In addition, weak forest management practices, including the suppression of natural fires, for many years have led to the accumulation of flammable underbrush. S. Ross Gorte, The Rising Cost of Wildfire Protection 2-3 (2013), available at http:// pagosaspringscdc.org/wp-content/uploads/2013/07/Rising-Costs-of-Wildfire-Protec tion-Headwaters.pdf (attributing the accumulation of forest fuels largely to "20th century fire suppression policies that sought to eliminate all wildfires" and noting that "current levels of fuel reduction treatments are inadequate to even stabilize the current fuel levels, since forests continue to grow, adding more biomass to the lands"). Building codes have received more attention in recent years, but older construction tends to have characteristics that fuel the spread of wildfires once they reach inhabited areas. See, e.g., Stephen L. Quarles et al., Univ. Cal. Agric. \& Nat. Resources, Pub. No. 8393, Home Survival in Wildfire-Prone Areas: Building Materials AND Design Considerations 13-14 (2010), available at https://anrcata log.ucanr.edu/pdf/8393.pdf (explaining that deck board choice, deck design, and deck maintenance can minimize a deck's exposure to embers and that California requires minimum performance standards for deck boards on new homes). See also Tim Wallace et al., Three of California's Biggest Fires Ever Are Burning Right Now, N.Y. Times (Aug. 10, 2018), https://www.nytimes.com/interactive/2018/08/10/us/californiafires.html [https://perma.cc/PX59-MQ3G] (noting that "[i]n 2010, California became one of the few states in the country to adopt a mandatory statewide building code to help reduce fire risk in wildfire-prone areas"). Addressing the core contributing factors to the increasing wildfire risk is not easy. For example, as wildfires increase in frequency and intensity, the priorities for investment within forest management programs shift as budgets are shifted from programs to improve forest management, which reduces wildfire risk, to the expenses of firefighting. See Office OF EnvtL. Health Hazard Assessment, Cal. Envtl. Protection Agency, Indicators of Climate Change in California 188 (2018), available at https://oehha.ca.gov/media/ downloads/climate-change/report/2018caindicatorsreportmay2018.pdf ("As large wildfires increase in size and number and the fire season has grown longer, firefighting consumes more of the annual resource management budgets for federal and state lands that otherwise could be spent on sustainable programs for fuel management and forest health.")

31. See U.S. Volcanoes and Current Activity Alerts, USGS, https://volcanoes.usgs .gov/index.html (last updated Nov. 27, 2018) [https://perma.cc/JQ7X-5GZV] (showing a map of volcanoes and current activity across the western U.S. mainland, Hawaii, and Alaska). Hawaii's Kilauea Volcano provides a recent example of the destructive and disruptive nature of volcanic eruptions; the long-lasting eruption prompted evacuations and destroyed hundreds of homes over the course of weeks. "A Lot of Tears": Lava Destroys as Many as 700 Homes in Hawaii, CBS News, https://www.cbsnews .com/news/hawaii-kilauea-volcano-big-island-lava-destroys-as-many-as-700-homes-in- 
severe thunderstorms and wind ${ }^{33}$ hail,${ }^{34}$ blizzards and snowfall, ${ }^{35}$ ice storms, ${ }^{36}$ and extreme temperature events. ${ }^{37}$ Not all of these perils

hawaii/ (last updated June 12, 2018) [https://perma.cc/4D56-TEQ2]. By comparison, Mount St. Helens erupted in May 1980 in a violently explosive manner, killing fiftyseven people. See Alan Taylor, Mount St. Helens and the Fear of Not Knowing, ATLANTIC (May 18, 2018), https://www.theatlantic.com/science/archive/2018/05/mt-sthelens-volcano-before-the-internet/560684/ [https://perma.cc/UD6Z-MGVG] ("It was preceded by the largest landslide ever recorded. It shortened the volcano by about 1,300 feet, generated a blast heard 200 miles away, and spent nine hours spewing 500 million tons of ash 15 miles into the sky, which then fell across at least 11 states and parts of Canada.").

32. See U.S. Tornado Climatology, Nat'L Ctrs. for Envtl. Info., https://www. ncdc.noaa.gov/climate-information/extreme-events/us-tornado-climatology (last visited June 27, 2018) [https://perma.cc/CWL7-F395] (noting an average of 1,253 tornadoes in the U.S. each year). The highest number of tornadoes occur in Tornado Alley-"a nickname given to an area in the southern plains of the central United States" - and in Florida. Tornado Alley, NAT'L CTRS. FOR ENVTL. Info., https://www. ncdc.noaa.gov/climate-information/extreme-events/us-tornado-climatology/tornado-al ley (last visited June 27, 2018) [https://perma.cc/8WH2-Q6UK].

33. See Severe Weather 101: Thunderstorm Basics, NAT'L Severe Storms Lab., https://www.nssl.noaa.gov/education/svrwx101/thunderstorms/ (last visited June 27, 2018) [https://perma.cc/CKT4-M2ZR] (noting that severe thunderstorms-those with hail larger than an inch, winds above 57.5 miles per hour, or tornadoes-are most common from Texas to southern Minnesota).

34. See Jonathan Belles, We're Coming up on the Peak of Activity in Hail Alley, Weather Channel (May 18, 2018), https://weather.com/storms/severe/news/hail-cli matology-united-states [https://perma.cc/654F-K65H] (noting that "[s]evere hail occurs most often in a triangular region from west Texas to northwest Missouri to the western Dakotas").

35. See Nick Wiltgen, The Snowiest Place in Each State, Weather Channel (Oct. 27, 2016), https://weather.com/safety/winter/news/snowiest-places-most-snow [https:// perma.cc/RT5B-VHNN] (identifying the highest snowfall totals over a 30-year period for each state and noting large differences between regions). The National Weather Service classifies a "blizzard event" as having "[s]ustained wind or frequent gusts greater than or equal to $35 \mathrm{mph}$ will accompany falling and/or blowing snow to frequently reduce visibility to less than $1 / 4$ mile for three or more hours." National Weather Service Expanded Winter Weather Terminology, Nat'L Weather Serv., https://www.weather.gov/bgm/WinterTerms (last visited June 27, 2018) [https:// perma.cc/4MQD-EAV6]. The frequency of blizzards is on the rise. Jill S.M. Coleman \& Robert M. Schwartz, An Updated Blizzard Climatology of the Contiguous United States (1959-2014): An Examination of Spatiotemporal Trends, 56 J. Applied MeteORology \& Climatology 173, 176 ("Seasonal blizzard frequencies displayed a distinct upward trend, with a more substantial rise over the past two decades."). Blizzard occurrence has become more widespread but is most associated with the northern Great Plains. Id.

36. See Chris Dolce \& Jon Erdman, The Nation's Worst Ice Storms, WeAther Channel (Jan. 11, 2017), https://weather.com/storms/winter/news/top-10-worst-icestorms-20131205 [https://perma.cc/L3PW-YPVR] (discussing storms across many states). Ice storms are characterized by "damaging accumulations of ice" that often result in severe travel dangers. Ice Storm, NAT'L WeAther SERV., https://forecast. weather.gov/glossary.php?word=ice\%20storm (last visited June 27, 2018) [https://per ma.cc/8E9J-KSQ7].

37. See Rebecca Lindsey, Influence of Global Warming on U.S. Heat Waves May Be Felt First in the West and Great Lakes Regions, Climate.gov (Apr. 2, 2018), https://www.climate.gov/news-features/featured-images/influence-global-warming-usheat-waves-may-be-felt-first-west-and [https://perma.cc/9RGR-V775] (noting heat wave clusters in the West, Northern Plains, Southern Plains, and Great Lakes regions 
carry a high risk of fatalities, although all carry some risk. The good news is that only $1.1 \%$ of the total U.S. land area is at high mortality risk due to exposure to two or more natural disaster hazards. ${ }^{38}$ The bad news is that more than one-third of the U.S. population lives in that $1.1 \%$ of land area. ${ }^{39}$ Worse, a majority of the U.S. population is exposed to at least one major natural disaster hazard, which carries the potential for widespread destruction of property and life. ${ }^{40}$ The combined geographic coverage of these individual natural hazards essentially blankets the U.S. and could potentially impact the entire population. ${ }^{41}$ And the frequency and intensity trend lines for natural disasters generally are not encouraging; 2017 set a record for the costliest year ever for natural disasters, with $\$ 306$ billion in total damage. ${ }^{42}$

With the data showing that hurricanes are the most likely and serious of all of these disasters, we return to Hurricane Harvey. ${ }^{43}$ No one living in Texas-especially in the cities of Houston, Port Arthur, Bridge City, Rockport, Wharton, Conroe, Port Aransas, and Victoria, or more generally in the counties of Harris, Aransas, Nueces, Jefferson, Orange, Victoria, Calhoun, Matagorda, Brazoria, Galveston, Fort Bend, Montgomery, and Wharton-needs to be told that the U.S. needs a better approach to managing hurricane and other natural disaster risk, both in terms of pre-disaster planning and post-disaster recovery. ${ }^{44}$ Texans are not alone, as survivors of Hurricanes Katrina,

over areas with high population densities and highlighting that "more people in the United States die each year from heat-related illness than any other weather disaster"); Michael J. Allen \& Scott C. Sheridan, Spatio-Temporal Changes in Heat Waves and Cold Spells: An Analysis of 55 U.S. Cities, 37 Physical Geography 189, 203-05 (analyzing extreme cold events over two periods for various U.S. cities and emphasizing that "[w]ith increasingly mild winters, populations may become desensitized to cold spells"); Jon Erdman, America's Coldest Outbreaks, Weather Channel (Jan. 17, 2018), https://weather.com/storms/winter/news/america-coldest-outbreaks [https:// perma.cc/7GX4-BCP3].

38. See Maxx Dilley et al., World Bank Hazard Mgmt. Unit, Natural Disaster Hotspots: A Global Risk Analysis 9 (2005), available at http://docu ments.worldbank.org/curated/en/621711468175150317/Natural-disaster-hotspots-Aglobal-risk-analysis.

39. See id.

40. See id. at 11 (showing on a map that between $51 \%$ and $75 \%$ of the U.S. population is in the highest risk areas from one or more hazards).

41. See generally Kate Baggaley, Where in the United States Is Nature Most Likely to Kill You?, Popular SCI. (June 14, 2017), https://www.popsci.com/natural-hazardrisk [https://perma.cc/R5AN-ARW3].

42. Chris Mooney \& Brady Dennis, Extreme Hurricanes and Wildfires Made 2017 the Most Costly U.S. Disaster Year on Record, WAsh. Post (Jan. 8, 2018), https://www. washingtonpost.com/news/energy-environment/wp/2018/01/08/hurricanes-wildfiresmade-2017-the-most-costly-u-s-disaster-year-on-record/ [https://perma.cc/H2VUAUHR].

43. See supra notes 5-16 and accompanying text.

44. See Audrey Carlsen \& K.K. Rebecca Lai, Where Harvey Hit Hardest Up and Down the Texas Coast, N.Y. TIMEs (Sept. 1, 2017), https://www.nytimes.com/interac tive/2017/09/01/us/hurricane-harvey-damage-texas-cities-towns.html [https://perma.cc/ 64Z6-TSZ5]; Matt Keyser, Report Highlights Top 20 Areas Hit Hardest by Hurricane 
Sandy, Irma, Maria, Florence, Michael, and others will be quick to agree. This Article primarily examines hurricane risk through the optic of insurance, but, as the discussion will show, a much larger lens is needed if we are to have a chance of improving our management of this enormous, and growing, problem.

\section{The Elements of Natural Disaster Risk Management AND RECOVERY}

\section{A. The Current "National Preparedness" Framework}

Because natural disasters are so vast in their consequences, strategies to deal with them must be varied, interdependent, and coordinated. The need for national planning to prepare for international threats has long been understood, but the appreciation of the national security and welfare implications of catastrophic natural disasters has developed more recently. ${ }^{45}$

Although some examples of planning in response to national threats can be found in the history of World War I ${ }^{46}$ the civil defense efforts during World War II marked the first significant attempt to coordinate national civil preparedness. ${ }^{47}$ These efforts continued during the Cold

Harvey, KHOU 11 (Nov. 21, 2017), https://www.khou.com/article/weather/harvey/re port-highlights-top-20-areas-hit-hardest-by-hurricane-harvey/285-493668432 [https:// perma.cc/854C-VNSH].

45. War and terrorism are the primary examples, but the coordinated national response to the global $\mathrm{Y} 2 \mathrm{~K}$ threat and current concerns over election security in response to Russian efforts to hack the 2016 domestic elections show that cybersecurity belongs on this list. See Graham Lanktree, U.S. Government at Risk of "Terrifying" Hacking Attack, but Trump Won't Do More to Fix the Problem, Newsweek (July 5, 2017, 11:14 AM), https://www.newsweek.com/trump-wont-raise-hacking-putin-yet-usgovernment-massively-vulnerable-says-63206 [https://perma.cc/RH9F-US5P]. Proposed action by the federal government suggests that cybersecurity threats will be addressed more efficiently in the future. See Lily Hay Newman, DHS Will Shore Up Cybersecurity for America's Infrastructure, WIRED (July 31, 2018), https://www. wired.com/story/dhs-national-risk-management-center/ [https://perma.cc/VTV9-29 HU] (reporting on the proposed creation of a National Risk Management Center and the DHS Cyber Incident Response Teams Act of 2018).

46. See James F. Miskel, Disaster Response and Homeland Security: What Works, What Doesn't 41 (2006) (noting that the War Department established the first "institutionalized disaster relief program" in 1917 through Special Regulation Number 67, Regulations Governing Flood Relief Work of the War Department - these regulations set out "the basic policies that would be applied ... to all natural disasters").

47. U.S. Dep't of Homeland Sec., Quadrennial Homeland Security Review Report: A Strategic Framework for a Secure Homeland 11 (2010), available at https://www.dhs.gov/xlibrary/assets/qhsr_report.pdf ("The National Security Act of 1947 brought together the Department of War and the Department of the Navy into a single integrated entity that became the Department of Defense. The Act also created the National Security Council and a position on the President's staff that would later become the National Security Advisor. The innovation was to bring together under one overall concept the consideration of foreign affairs and military policy, which had been, up until that time, two largely separate governmental domains."). 
War, ${ }^{48}$ and the rise of terrorism-manifested most vividly in the World Trade Center and Pentagon attacks ${ }^{49}$ - elevated homeland security's prominence among the federal government's priorities. ${ }^{50}$ Indeed, the September 11, 2001 attacks focused the national preparedness conversation in ways that had not occurred since World War II. ${ }^{51}$

It was not, however, until Hurricane Katrina made landfall in the coastal areas of Louisiana, Mississippi, and Alabama in 2005 that natural disasters became part of the national preparedness conversation. ${ }^{52}$ As Hurricane Katrina came ashore, the lack of effective state and local planning became obvious; many citizens were unprepared or unwilling to implement disaster response strategies, and the federal government's response was late, disorganized, and frequently ineffective. ${ }^{53}$ In direct reaction to these failures, Congress passed the Post-

48. George D. Haddow \& Jane A. Bullock, Introduction to Emergency MANAGEMENT 2-3 (2d ed. 2006) (noting that state and local authorities played a large role in emergency management during this period, but also describing the establishment of the Office of Defense Mobilization for efficiently handling resource needs and the role of the Federal Civil Defense Administration in dispensing technical guidance; these agencies merged in 1958).

49. Attacks on the U.S.S. Cole in 2000 and the World Trade Center in 1993, the domestic terrorist attack in Oklahoma City in 1995, and the U.S. embassy bombings in Kenya and Tanzania in 1998 heightened civic attention on the potentially catastrophic implications of a terrorist attack. See Chris Weller, Startling Maps Show Every Terrorist Attack Worldwide Over the Last 20 Years, Business INSIDER (Nov. 1, 2017, 10:16 AM), https://www.businessinsider.com/global-terrorist-attacks-past-20years-in-maps-2017-5 [https://perma.cc/26NQ-VJLG]; Historic Timeline, NAT'L COUnTERTERrorism CTR., https://www.dni.gov/nctc/timeline.html (last visited Aug. 26, 2018) [https://perma.cc/3W7N-CQ7F].

50. Homeland Sec. Nat'l Preparedness Task Force, Civil Defense and Homeland Security: A Short History of National Preparedness Efforts 23-25 (2006), available at https://training.fema.gov/hiedu/docs/dhs\%20civil\%20de fense-hs\%20-\%20short\%20history.pdf (noting that post-September 11, 2001, "there was near universal agreement within the Federal government that homeland security required a major reassessment, increased funding, and administrative reorganization").

51. See Kathleen J. Tierney, Recent Developments in U.S. Homeland Security Policies and Their Implications for the Management of Extreme Events, in HANDBOOK OF DisAster Research 406 (Havidán Rodríguez et al. eds., 2007) ("The creation of the Department of Homeland Security (DHS) was perhaps the most visible policy response to the events of September 11. The government reorganization that accompanied the formation of DHS was the largest in U.S. history since President Truman created the Department of Defense in 1947, incorporating all or part of 22 federal agencies, 40 different federal entities, and approximately 180,000 employees.").

52. For a discussion of the history of national preparedness planning, see Irwin Redlener \& David A. Berman, National Preparedness Planning: The Historical Context and Current State of the U.S. Public's Readiness, 1940-2005, 59 J. InT'L AfFaIRs 87 (2006).

53. Frances Fragos Townsend et al., The Federal Response to HurriCANE Katrina: Lessons LeARned 33-50 (2006), available at https://permanent.access.gpo.gov/lps67263/katrina-lessons-learned.pdf (detailing the "week of crisis" as Hurricane Katrina made landfall and overwhelmed past response efforts before concluding that "[t]he Federal government's problems responding to Hurri- 
Katrina Emergency Management Reform Act (the "Act") in 2006. ${ }^{54}$ In this Act, Congress, among other things, substantially reorganized the Federal Emergency Management Agency ("FEMA"), gave it new authority to remedy apparent gaps in local, state, and federal response efforts, and identified "preparedness, protection, response, recovery, and mitigation" as FEMA's five core missions. ${ }^{55}$ Notably, these five missions, viewed as a whole, established a federal governmental role in all phases of a natural disaster, including pre-disaster planning and preparation, civil protection as a disaster unfolds, and post-disaster relief.

Under the authority of this Act, President Obama issued "Presidential Policy Directive 8: National Preparedness," 56 which articulated a goal of creating "[a] secure and resilient Nation with the capabilities required across the whole community to prevent, protect against, mitigate, respond to, and recover from the threats and hazards that pose the greatest risk." 57 This directive embraced an integrated, compre-

cane Katrina illustrate greater systemic weaknesses inherent in our current national preparedness system: the lack of expertise in the areas of response, recovery, and reconstruction").

54. U.S. Gov't Accountability Off., GAO-09-59R, Actions to Implement the Post-Katrina Act 2 (2008).

55. The five-part mission language comes from the 2006 statute reforming FEMA in the wake of Hurricane Katrina. See infra note 60 . Today, most policy analysts describe homeland security in terms of the five missions stated in PPD-8 and which appear in the 2006 statute: prevention (of the events themselves); protection (of citizens against the events as they occur); mitigation (of the consequences of the events); response (to the events as they occur); and recovery (in the aftermath of the events). With terrorism, the national focus is on prevention. With natural disasters, thus far the national focus has been on after-the-fact response and recovery. Jason Barnosky, Before the Storm: Shifting Federal Disaster Policy Toward Mitigation, Brookings (Feb. 19, 2015), https://www.brookings.edu/blog/fixgov/2015/02/19/before-the-stormshifting-federal-disaster-policy-toward-mitigation/ [https://perma.cc/4N8J-M5KN]. The 2006 statute marked an important point in the evolution in the understanding of the elements of emergency management. For many years before the statute, the mantra of emergency management was "mitigation, preparedness, response, and recovery." The George W. Bush administration, responding to heightened focus on terrorism catastrophes, sought to replace "mitigation" with "prevention." Congress did not do this in the 2006 statute, but did add protection to the four factors; obviously, "protecting" the homeland had much more resonance after the 9/11 attacks.

56. U.S. Dep't Homeland Sec., Presidential Policy Directive/PPD-8: NATIONAl PREPAREDNESs, available at https://www.dhs.gov/presidential-policy-directive8-national-preparedness. See Jared T. Brown, Cong. Res. Serv., Presidential Policy Directive 8 and the National Preparedness System: Background AND Issues FOR CONGRESS (2011), available at https://fas.org/sgp/crs/homesec/ R42073.pdf.

57. The 2011 Obama directive retained both "mitigation" and "prevention" among the five goals, added "protection," and deleted "preparedness." The directive listed these five elements as part of creating a "secure and resilient nation." Perhaps because the term "security" has a closer logical nexus to war, terrorism, cyberattacks, and other similar threats to the homeland, FEMA appears to stress resilience as the primary objective of its natural disaster relief strategies. See Resilience, FEMA, https:/ /www.fema.gov/resilience (last visited Dec. 10, 2018) [https://perma.cc/LR5L-FHSC]. "Resiliance," however, is also a term emphasized in the mission statements of the 
hensive, "all hazards, capability-based approach" to national preparedness. ${ }^{58}$ It recognized that threats to national security come from a diverse range of hazards, including natural disasters, pandemics, terrorist acts, accidents-such as dam failures, chemical spills, and infrastructure failures-and cyber-attacks. The directive also recognized that the U.S. needs a coherent overarching strategy to respond to all these hazards. ${ }^{59}$ Although the nomenclature of national preparedness has evolved and will continue to do so, the current lexicon of catastrophe risk management appears in Figure 1.

Department of Homeland Security, as this term also aptly describes the nation's preparation for terrorism and other kinds of internationally-based threats. See Resilience, Dep't Homeland Sec., https://www.dhs.gov/topic/resilience (last visited Dec. 10, 2018) [https://perma.cc/EDM7-8FJB]. FEMA describes resilience as "a culture of preparedness through insurance, mitigation, preparedness, continuity, and grant programs." Id. Separately, in explaining the National Preparedness Goal, FEMA identifies 32 activities, called "core capabilities," that "address the greatest risks to the nation," and the National Preparedness Goal organizes the thirty-two activities into "five mission areas," which are the same five missions in the Obama 2011 policy directive.

58. U.S. Dep't Homeland Sec., National Preparedness Goal 3 (1st ed. 2011), available at https://www.fema.gov/pdf/prepared/npg.pdf. The directive was amplified in a report published by the Department of Homeland Security later that year. See U.S. Dep't Homeland Sec., National Preparedness Goal 1 (1st ed. 2011), available at https://www.fema.gov/pdf/prepared/npg.pdf. The report was modified in 2015. See generally U.S. Dep't Homeland Sec., National Preparedness Goal (2d ed. 2015), available at https://www.fema.gov/media-library-data/14437996151712aae90be55041740f97e8532fc680d40/National_Preparedness_Goal_2nd_Edition.pdf. This directive and efforts to implement it should be viewed as an extension of a history of national preparedness initiatives dating back to World War II. See Redlener \& Berman, supra note 52.

59. Id. 


\section{The Current National Preparedness Framework for Catastrophe Risk Management}

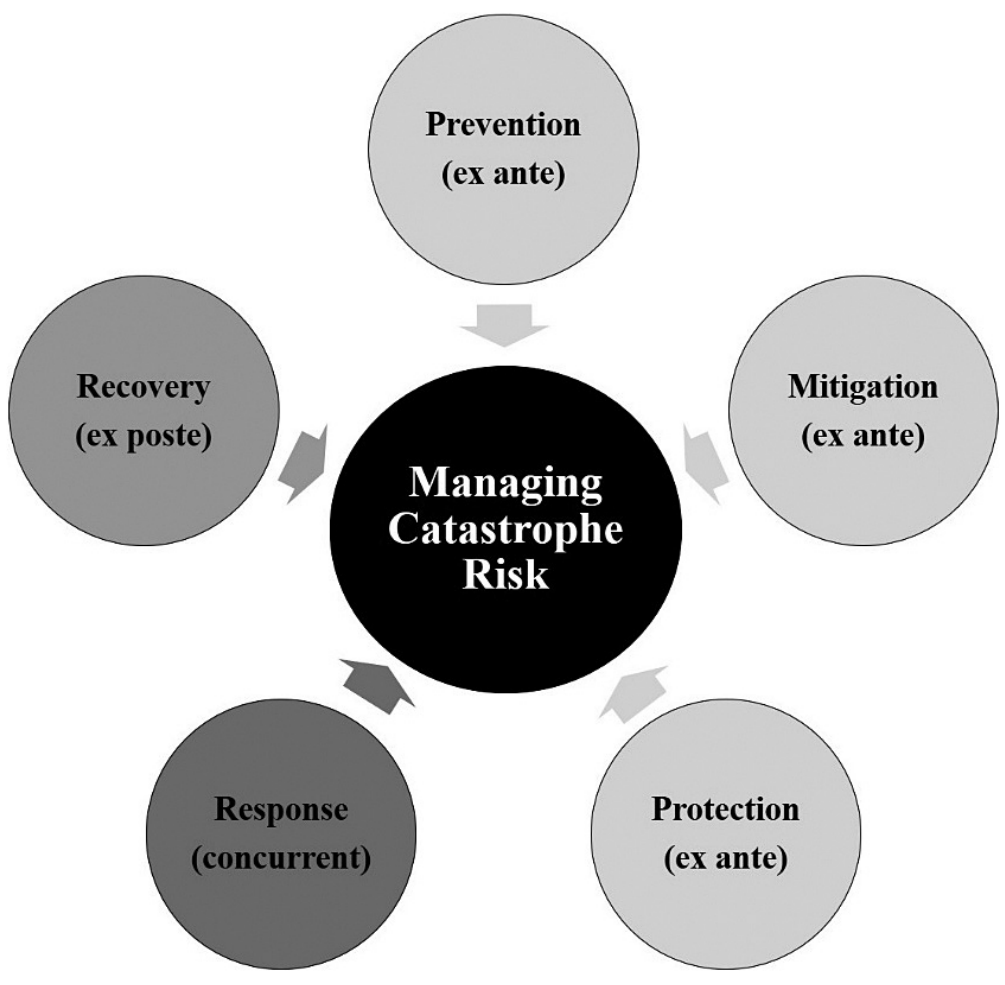

Consistent with the Act and the Obama policy directive, this framework recognizes five core missions in managing catastrophe risks. ${ }^{60}$ Prevention refers to avoiding or stopping an occurrence; this mission is most commonly implicated with terrorism and other human-induced assaults on the country. ${ }^{61}$ Protection refers to securing or hardening the means through which a nation defends citizens, property, systems, networks, and other assets from the effects of such occurrences as they unfold. ${ }^{62}$ Mitigation refers to steps a nation takes to lessen the

60. In some discussions, each of these missions is described as a "framework." For example, the Congressional Research Service has described the National Preparedness System as involving five "National Planning Frameworks," which are the same as the five core missions. See Jared T. Brown, Cong. Research Serv., R42073, Presidential Policy Directive 8 and the National Preparedness System: BackGROUND AND IsSUES FOR CONGRESS 10 (2011).

61. An example of this is civic education to encourage citizens to report strange packages left unattended in public spaces, airports, etc.

62. An example of this is retrofitting computer systems, servers, and components to resist attacks from cyber-hackers. 
impact on people and property of future disasters. ${ }^{63}$ Response refers to the actions a nation takes as a disaster unfolds to save lives and protect property and other assets and to meet human needs in the aftermath of an occurrence. ${ }^{64}$ Recovery refers to restoring and rebuilding in the aftermath of an occurrence. ${ }^{65}$ Although the boundaries among some of these missions are imprecise, they provide a coherent framework for the discussion and organization of planning, policymaking, and strategy implementation.

\section{B. Insurance and the National Preparedness Framework}

\section{Recovery, Prevention, and Mitigation}

Insurance is closely related to three of the national preparedness missions: recovery, prevention, and mitigation. The most obvious connection is recovery; insurance companies pay proceeds to individuals and firms that suffer losses, and the recipients use these funds to rebuild, rehabilitate, and sometimes relocate. Recovery is the post-event phase, whereas the decision to purchase insurance is made ex ante as part of the process of preparing for a possible catastrophe. The timing of the purchase is related to insurance law's fortuity requirement, which holds that insurance cannot be purchased after a loss, once a loss is in progress, or once it is known that a loss will occur or will soon begin to occur. ${ }^{66}$ For individuals with losses and public officials responsible for rebuilding communities and their infrastructures, insurance has an important connection to recovery. When, however, an individual chooses to purchase insurance, the transaction has a close nexus to mitigation. The prospective insured is interested in transferring risk to the insurer by paying a premium in exchange for the insurer's promise to pay recovery expenses if the insured suffers a loss, so that the insured's out-of-pocket expenses in the recovery phase will be reduced. What, at least in theory, makes this exchange feasible and affordable is the insurer's ability to pool the insured's risk with large numbers of similarly situated insureds. The insurer-with the knowledge afforded by the law of large numbers that not all insureds in the pool will suffer losses in a given policy term-is able to charge all insureds in the pool a premium that is a fraction of an insured's poten-

63. An example of this is retrofitting homes with hurricane shutters and roof straps to reduce hurricane damage.

64. The activities of first-responders (i.e., police, fire, Coast Guard, National Guard, etc.) in rescue, temporary relocation, etc. are examples of the implementation of this mission.

65. Debris removal, loans and grants, permanent relocation assistance, insurance payments, etc. are examples of implementation of this mission.

66. See Robert H. Jerry \& Douglas S. Richmond, Understanding InsurANCE LAW 368-76 (6th ed. 2018). 
tial total loss, thereby making the insured's insurance purchase affordable. ${ }^{67}$

Insurance is also indirectly related to prevention. The business of insurance is first and foremost the business of managing risks; insureds purchase insurance to substitute security for uncertainty, which is a financial cost that deters us from valuable activities, a psychological burden, or both. But to the extent individuals and firms can prevent events that cause loss, they will not need insurance to compensate for loss. Similarly, to the extent individuals and firms succeed in reducing the probability that loss-producing events will happen, the insurance they purchase should cost less. Thus, individuals and firms invest substantial resources in trying to prevent events that cause loss. The insurance industry supports those efforts by studying risks and losses, educating policyholders about how to reduce risk, and structuring their products-such as deductibles, copayments, and self-insured retentions-to incentivize policyholders to engage in loss-prevention activities.

Prevention, if understood as averting the occurrence of the loss-producing event itself, is irrelevant as a risk management technique for natural disasters. It is not yet-and may never be-possible to control the timing, nature, or magnitude of hurricanes and other natural disasters. ${ }^{68}$ If, however, prevention is understood as preventing an event's consequences from becoming a catastrophe, the concept of prevention is highly relevant to natural disasters. For example, in almost every natural disaster situation, putting physical distance between persons and property and the source of a disaster reduces the risk of loss when the event occurs. Prevention options exist in some other situations as well. For example, human negligence sometimes causes wildfires, but wildfire prevention education has demonstrated net benefits by reduc-

67. This necessitates disaggregation of risk, or the avoidance of correlated risks, so that all insureds in the pool will not suffer similar losses in the event of a disaster. For a discussion of the law of large numbers, see id. at 13 .

68. There is a possibility that an asteroid strike could end almost all life on the planet. See Brett Line, Asteroid Impacts: 10 Biggest Known Hits, Nat'L Geographic (Feb. 15, 2013), https://news.nationalgeographic.com/news/2013/13/130214-biggest-as teroid-impacts-meteorites-space-2012da14/ [https://perma.cc/QG3E-WS6R] (cataloging the ten biggest known asteroid impacts). The risk is high if "risk" is defined as the probability of the occurrence times the magnitude of the loss, while considering coping capacity. See Ulrich Ranke, Natural Disaster Risk Management: Geosciences and Social Responsibility 491 (2015); David J. Eicher, Why the Asteroid Threat Should be Taken Seriously, Astronomy (Apr. 2, 2015), http://www.astron omy.com/bonus/asteroidday [https://perma.cc/47AM-JC2N]. Modern technology may prevent the catastrophic event. For a discussion on how spacecraft systems can be used to prevent impacts, see Detecting \& Mitigating the Impact of EarthBound Near-Earth Objects Interagency Working Group, Nat'l Science \& Technology Council, National Near-Earth ObJect Preparedness StratEGY AND ACTION Plan 4-5 (2018), available at https://www.whitehouse.gov/wp-con tent/uploads/2018/06/National-Near-Earth-Object-Preparedness-Strategy-and-Action -Plan-23-pages-1MB.pdf. 
ing the occurrence of some kinds of wildfires. ${ }^{69}$ Additionally, rain and snowmelt that cause flooding are uncontrollable, but sometimes watershed, stream, and river management practices can prevent some land areas from flooding during these uncontrollable weather events. When insurers reduce premiums in response to insureds' efforts to prevent adverse events or to divert or minimize an event's consequences, insurance incentivizes investment in prevention.

A related but distinct risk management tool is mitigation-reducing the magnitude of loss once it occurs. This strategy is so familiar in our daily lives that most of us overlook its presence: sprinkler systems in our buildings will not prevent fires from breaking out, but they will reduce their consequences; seat belts, air bags, and no-crush passenger compartments will not prevent auto accidents, but they do reduce the likelihood of injury when an accident occurs; carbon monoxide and smoke alarms will not prevent furnace malfunctions and house fires, but they do provide warnings that help save lives. Every kind of natural disaster is susceptible to loss-reduction strategies. For example, faulty forest-management practices and antiquated building codes and zoning regulations magnify the impact of wildfires, and revising or updating these practices and regulations can reduce the amount of wildfire loss. ${ }^{70}$ Building codes can mitigate the impact of earthquakes, ${ }^{71}$ and early warning systems can reduce the risk to life when the system spots a tornado. ${ }^{72}$ Severe hot and cold weather is uncontrollable, but public and private programs to assist vulnerable populations- the eld-

69. See, e.g., Jeffrey P. Prestermon et al., Net Benefits of Wildfire Prevent Education Efforts, 56 FOREST SCI. 181, 188 (2010) (concluding that wildfire education efforts have statistically significant, beneficial effects on the number of wildfires ignited by debris burning, campfire escapes, smoking, and children, with a benefits-to-costs ratio for Florida wildfires from 2002 to 2007 of an average of 35:1).

70. See, e.g., Thomas Curwen, California's Deadliest Wildfires Were Decades in the Making, L.A. Times (Oct. 22, 2017, 5:00 AM), http://www.latimes.com/local/califor nia/la-me-fire-perspectives-20171022-story.html [https://perma.cc/3T6M-PTY9] (describing the position that fire management is a "societal and political problem" and that part of the solution involves "allowing more controlled burns, and ... applying the same citywide codes and zoning requirements to rural subdivisions").

71. See e.g., Nat'l Inst. Of Bldg. Scis. Bldg. Seismic Safety Council, EarthQuake-Resistant Design Concepts: An Introduction to the NEHRP Recommended Seismic Provisions for New Buildings and Other Structures 7-11 (2010), available at https://www.fema.gov/media-library-data/20130726-1759-250455477/fema_p_749.pdf (detailing the history of seismic requirements for building codes and the impact of the federal National Earthquake Hazards Reduction Program on improvements to today's building codes).

72. Timothy A. Coleman et al., The History (and Future) of Tornado Warning Dissemination in the United States, 92 BAMS 567, 568 (2011). See also Mildred F. Perreault, Does Scary Matter?: Testing the Effectiveness of New National Weather Service Tornado Warning Messages, 65 Comm. STud. 484, 488-89 (describing more recent efforts by the National Weather Service to create more effective warning messages that "include more frightening information (when appropriate) and more detail on tornado path and recommended actions"). 
erly or the homeless, for example-can reduce the risk of injury or death.

Whether the foregoing strategies' categorization in the national preparedness lexicon should be prevention or mitigation is arguable ${ }^{73}$ regardless, loss-reduction and mitigation strategies are the first lines of defense against natural disasters. The purchase of insurance enters the picture only when one of two things happens: either (a) purchasers exhaust all options for loss reduction and mitigation and none remain for implementation; or (b) the marginal costs of implementing additional loss-reduction or mitigation options exceed the costs of purchasing insurance in markets where such products are available. If insurance providing compensation for loss is cheaper than the cost of implementing a loss-reduction or mitigation strategy, the rational economic actor will decline to implement the strategy and will purchase insurance instead.

In an efficient market, price adjustments by the insurer will influence how much investment insureds make in loss reduction and mitigation. An insurance company selling a policy that covers a particular kind of loss should offer the policyholder a premium reduction if the policyholder invests in one or more strategies that reduce the amount of loss that will occur should the loss-producing event happen. If the premium reduction is more than the cost of implementing the lossreduction or mitigation strategy, the rational policyholder should implement the strategy in order to maximize gains. But, if an insurer offers a premium reduction that is less than the cost of implementing the loss-reducing or mitigation strategy, the rational policyholder should decline to invest in the strategy and should purchase insurance instead. As in any market, price affects the amount of the product buyers will purchase; in insurance markets, this means that insurance premiums directly affect insureds' risk management choices.

Thus, in an efficient market, insurance works hand-in-hand with loss-prevention strategies to incentivize policyholders to take optimal steps to reduce the costs of hurricanes and natural disasters. Unfortunately, as discussed in Part III, the risk-management choices made in today's markets fall well short of this efficiency ideal.

73. "Prevention" and "mitigation" are difficult concepts to distinguish from one another. For example, with respect to flood risk, choosing to move from a coastal area to live on a mesa in the southwest will prevent loss due to flood (or mitigate up to $100 \%$ ), whereas moving inland from the coast will incrementally reduce the risk of hurricane-caused flooding in proportion to the distance moved if all other variables are held constant. An alternative possible distinction is as follows: A prevention strategy involves measures that keep people distant from flood waters, e.g., spatial planning and water-flow management, whereas a mitigation strategy involves measures that resist or accommodate the water, such as building codes that adapt a building to withstand the effects of flooding, e.g., building a structure on "stilts" so that flood water flows underneath it without destroying the first floor, at least if water levels stay below what is accommodated by the structural design. 


\section{Ex Ante Risk Management and Ex Post Damage Relief}

The five core missions in the modern national preparedness framework relate to each other sequentially: prevention, mitigation, and protection are pre-disaster-ex ante-activities; response activities are concurrent with the disaster; and recovery refers to post-disaster-ex post-activities. ${ }^{74}$ In other words, individuals and firms can either anticipate possible loss before it happens and act proactively to address the risk, wait for loss to happen and then respond to the consequences, or do some combination of both.

Ex ante strategies anticipate loss and seek to reduce either the likelihood of a loss-causing event or the magnitude of a loss. Individuals and firms engage in such activities, but so does government through direct investments and tools that require or incentivize private actors to do so. For example, government may require or incentivize ex ante strategies through tax incentives, direct subsidies (or cost-sharing), zoning regulations, land use planning rules, and building codes. These interventions are consistent with a long list of risk management strategies that government deploys throughout the economy, such as, for example, limited liability laws that cap losses for those taking entrepreneurial risks or provide valued goods and services in private markets; monetary policies and deposit insurance that reduce the risk of banking failures and associated volatilities in the economy; bankruptcy rules that shift default risk from debtors to creditors to prevent or ameliorate the financial collapse of individuals and firms; and product liability laws that manage the risk of product-caused injuries. ${ }^{75}$

Strategies that provide compensation to those who suffer the consequences of a loss-producing event are ex post damage relief techniques. Private insurance falls into this category, and government is also a major contributor to ex post compensation through direct insurance programs, such as flood insurance. ${ }^{76}$ In some settings, government regulations set the parameters for coverage provided by private insurers, which has the effect of determining compensation for injuries

74. An early use of the ex ante-ex post framework to describe national preparedness planning can be found in Howard Kunreuther, Mitigating Disaster Losses Through Insurance, 12 J. RISK \& UNCERTAINTY 171 (1996).

75. For more information on this, see David A. Moss, When All Else Fails: Government as the Ultimate Risk Manager (2002).

76. Other examples include the Social Security system, see id. at 180-215; Medicare, see Medicare.gov, https://www.medicare.gov/ (last visited Dec. 10, 2018) [https://perma.cc/U6HE-8XGN]; Medicaid, see MedicAID.Gov, https://www.medi caid.gov/ [https://perma.cc/JH7N-96VB]; and crop insurance, see 5 ROBERT H. JERRY, II, New Appleman on Insurance LaW Library Edition § 56 (2018). The risks of lacking sufficient income in old age or under conditions of disability are ameliorated by the Social Security program. The risks of lacking sufficient assets for medical and hospital expenses in old age or under conditions of indigency are ameliorated by the Medicare and Medicaid programs. 
and losses. ${ }^{77}$ Finally, government-provided disaster relief is a classic example of ex post risk management. ${ }^{78}$

Thus, strategies for risk management sort into ex ante and ex post categories. The aims of ex ante risk management strategies are to prepare for possible loss by preventing it where possible and mitigating its effects when encountered. The aims of ex post strategies are to enable recovery from the consequences already suffered. Insurance can also be understood as a method of ex ante preparation for ex post consequences. In an efficient market, insurance also serves to incentivize private investment in mitigation, thereby helping fulfill important ex ante goals. For ex post strategies, both insurance and disaster aid enable individuals and firms to rebuild or replace damaged property, to recover lost revenue streams, and to return to business or life as usual.

\section{Private Versus Public Risk Management}

As indicated in the prior discussion, risk management activities-in addition to being categorized as ex ante or ex post - can be categorized based on whether they originate in the private or the public sector. ${ }^{79}$ On the private side, individuals and firms prepare for disasters by investing in loss prevention and mitigation and by funding post-disaster recovery, either by purchasing insurance or by creating reserves for recovery (essentially self-insuring). Natural disaster risk management also occurs in the public sector. Although government often acts directly through various agencies to manage risk, it also acts indirectly through the influence it exercises on private actors.

In the private sector, the two insurance products most relevant to natural disaster losses are property insurance and business interruption insurance. Property insurance on buildings, homes, motor vehicles, and personal property can be obtained in homeowners, renters, and automobile policies, and some niche products, such as personal property floaters. Property insurance on commercial buildings and other kinds of business property is available in products tailored to commercial customers. Intangible assets are increasingly important in the modern e-economy, and a number of specialty products are now available to protect these kinds of assets. Business interruption insurance is an often overlooked but vitally important product in the commercial world. Business interruption insurance replaces income lost due to damage or loss of property on which the production of income depends. Property insurance replaces or repairs damage to tangible

77. Workers compensation insurance is an example. See Moss, supra note 75 , at $152-79$.

78. Id. at 253-64.

79. For a discussion of public versus private sector roles, see Carolyn Kousky \& Howard Kunreuther, Defining the Roles of the Public and Private Sector in Risk Communication, Risk Reduction, and Risk Transfer, Resources Future 1, 1 (2017). 
property, but often the far greater losses are the interruption of revenue streams when business activity ceases because property on which the activity depends is destroyed or damaged.

A premise of the U.S. economic system is that an unregulated marketplace is the default, and the government intervenes only when the market fails to achieve valued goals or make socially acceptable allocations. The business of insurance is subject to this same premise, and much of the history of governmental intervention in insurance markets involves efforts to shore up private markets when they fail. ${ }^{80}$ Yet the U.S. experience with hurricanes and other natural disasters demonstrates the incompleteness of the private market solution for ex post risk management. Moreover, that government should intervene after natural disasters strike and provide direct financial assistance to citizens has long been a deeply held expectation of the public. ${ }^{81}$ Thus, at numerous points in the natural disaster risk management-recovery matrix, government intervention has lacked effectiveness, efficiency, and coherence.

\section{The Natural Disaster Risk Management-Recovery Matrix}

With risk management activities sorting along two dimensions-ex ante risk management versus ex post recovery and private efforts versus public efforts-essentially four different categories of risk management activities exist. These categories are interdependent; an investment or activity in one affects the others. Government has its own ex ante and ex post activities but can also seek to influence or control decisions made in the private categories. These relationships are illustrated in Figure 2.

80. See JERRY \& Richmond, supra note 66, at 59.

81. See David A. Moss, Courting Disaster? The Transformation of Federal Disaster Policy Since 1803, in The Financing of Catastrophe Risk 307, 333, 343 (Kenneth A. Froot ed., 1999). 
FiguRE 2

\section{The Risk Management-Recovery Matrix ${ }^{82}$}

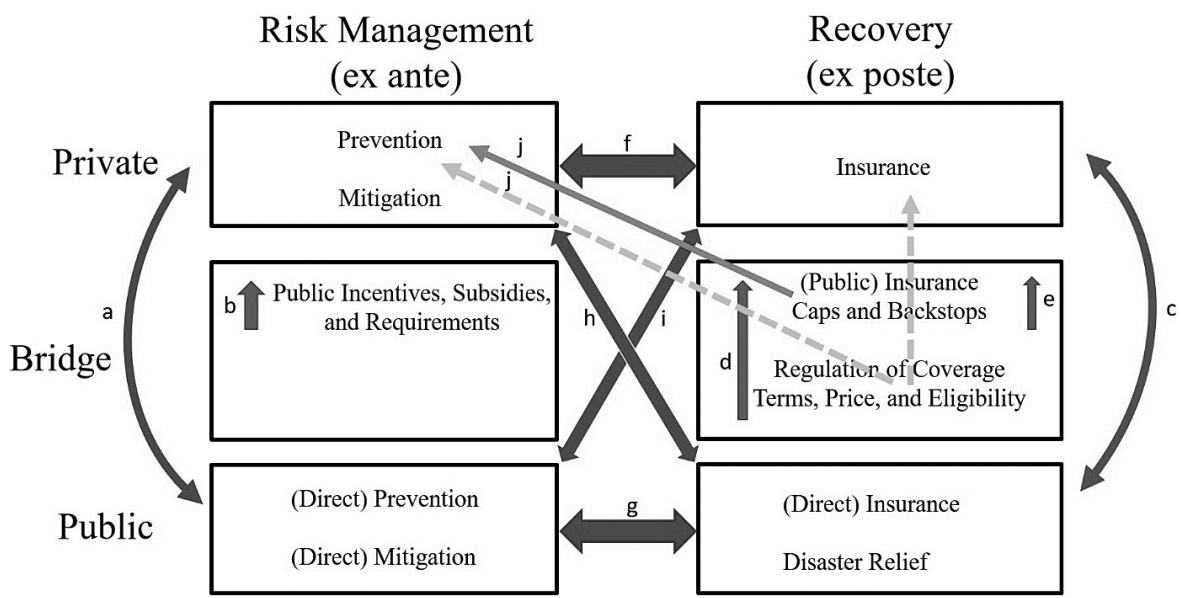

82. Notes: a. To the extent private investment in prevention and mitigation occurs, public investment is unnecessary. In reverse, public investment in prevention and mitigation will deter private investment if the private sector expects public investment to occur.

b. In the bridge, government can deploy means of incentivizing, subsidizing, and requiring private investments in mitigation and prevention.

c. To the extent private insurance is supplied and purchased, and/or private disaster assistance is supplied, government insurance and directly-provided disaster relief is unnecessary. To the extent government insurance and/or disaster relief is provided, private insurance is unnecessary. Also, the expectation of disaster relief may deter the purchase of private insurance.

d. Government regulation of private market coverage terms, price, and eligibility to purchase affects the availability of private insurance.

e. Government regulation of private market policy limits in the private market and government provision of excess layers of coverage influences the availability of insurance in the private market.

f. In the private sector, choices are made as to whether to invest in prevention and mitigation practices or to transfer risk to insurers in private markets. Doing either reduces the need for investment in the other.

g. Government chooses whether to invest in prevention and mitigation on the one hand, or to provide insurance and/or disaster relief on the other. A choice to invest in one reduces the need to invest in the other.

h. Private sector decisions to invest in prevention or mitigation reduce the need for the government to provide ex post insurance and/or disaster relief. Availability of government insurance and/or disaster relief can deter private investment in prevention and mitigation.

i. Public investments in prevention and mitigation can reduce the need for private sector purchases of insurance. To the extent private insurance is available and purchased in private markets, direct public investment in prevention and mitigation might be reduced.

j. To the extent government regulation of private insurance markets influences private market insurance availability, private market decisions regarding how much to invest in prevention and mitigation are affected. 
In a perfect risk management world, markets send clear signals to market participants, and these participants react by always making benefit-optimizing decisions. Where tradeoffs exist in the returns from different choices in the matrix, market participants will identify and implement the best choices. This, however, is not how the world actually functions. First, ex ante and ex post risk management activities are not perfectly coordinated. Underinvestment in pre-disaster prevention and mitigation leads to failure to prevent or reduce loss, which results in excessive reliance on post-disaster compensation. Second, within the private sector, investments in loss prevention and mitigation are not perfectly coordinated with insurance purchases. Market signals are often inaccurate, imperfectly communicated, and incorrectly interpreted. This prevents market participants from making optimal choices about when to cease further investments in prevention and mitigation and to shift to risk transference through the insurance purchases. Third, the purchase of private insurance is not perfectly coordinated with government insurance and public expenditures to subsidize private insurance purchases, and government insurance or subsidies sometimes disrupt private markets or exceed what is necessary to relieve market failure. Fourth, investment in pre-loss prevention and mitigation and pre-loss insurance-both private and publicis not perfectly coordinated with investment in post-loss disaster relief. Too little ex ante investment results in more costly expenditures for ex post relief. Fifth, within the prevention and mitigation facets, the mix of private spending and government subsidy is not perfectly coordinated within the prevention and mitigation areas of the matrix.

There are other tradeoffs in the matrix. ${ }^{83}$ Finding the optimal balance in each of these intersections is complicated: the empirical measurements needed to identify the points of perfect coordination are difficult to make, and in some instances, are probably impossible to confidently make with accuracy. Yet there is no escaping the matrix. It is within this complex set of relationships where the public policy choices appear and where public and private actors make the decisions that determine the nation's preparedness for hurricanes and other natural disasters.

\section{Hurricanes, the Matrix, And Natural Disaster MisMANAGEMENT}

As explained above, multiple points exist within the matrix where different kinds of natural disaster risk management strategies intersect. At each intersection, a range of potential outcomes exist depend-

83. For a comparative analysis of the tradeoffs in national preparedness policy, see Cathy Suykens et al., Dealing With Flood Damages: Will Prevent, Mitigation, and Ex Post Compensation Provide for a Resilient Triangle?, 21 Ecology \& Soc'y 1 (2016) (discussing natural flood disaster policy in Belgium, Netherlands, England, and France). 
ing on the chosen risk management strategy. This Section explores particularly challenging intersections in the matrix where four deficiencies in current approaches and strategies are especially salient: (1) underinvestment in prevention; (2) failures in private insurance markets; (3) ineffective government efforts to support private insurance markets; and (4) shortfalls in federal disaster relief programs. An important lesson of the matrix is that any effort to deal with any one of these challenges affects the others, which means that none of these problems can be effectively addressed in isolation.

\section{A. Underinvestment in Prevention}

Arguably the most important intersection in the matrix, and the one most confounding to current national preparedness policy, is the intersection where ex ante prevention and mitigation investments meet ex post recovery expenditures. To the extent investments in prevention and mitigation are successful, the need for post-event disaster relief and compensation declines. Unfortunately, current investments in prevention and mitigation are, by any fair measure, too low, which directly and significantly inflates the need for ex post recovery expenditures.

Part of the reason underinvestment in pre-loss prevention and mitigation occurs is directly related to the inherent proclivity of humans to underestimate hurricane risk.$^{84}$ Multiple cognitive biases contribute to these errors. First, humans tend to undervalue risks that are abstract or common and overvalue risks that are easily imaginable, horrific, beyond one's control, and widely publicized in the media. ${ }^{85}$ As this heuristic manifests itself with hurricanes, humans tend to overestimate their preparedness, underestimate the probability that the disaster will affect them personally, and underestimate the scope of the potential damage. ${ }^{86}$ This error not only produces underinvestment but also tends to cause public programs that encourage preparedness to underperform. ${ }^{87}$

84. Although this discussion is limited to hurricanes, most of the observations made in this discussion are equally pertinent to other kinds of natural disasters.

85. For more discussion, see Glynis M. Breakwell, The Psychology of Risk (2007); Bruce Schneier, Beyond Fear: Thinking Sensibly About Security in AN UnCERTAIN WORLD (2002).

86. See FM Global, Flirting with Natural Disasters: Why Companies Risk It All 7 (2010), available at http://www.fmglobal-touchpoints.co.uk/wp-content/ uploads/2012/04/Flirting-with-Natural-Disasters-Why-Companies-Risk-It-All_Flirting _with_natural_disasters.pdf. This heuristic is also manifest when investments in loss mitigation are made; a tendency exists to overestimate the effectiveness of the mitigation efforts and allow excessive development in areas mistakenly assumed to be protected, which itself can lead to greater future loss. See Howard Kunreuther, Disaster Mitigation and Insurance: Learning From Katrina, 604 Annals Am. Acad. Pol. \& Soc. SCI. 208, 208 (2006).

87. See Amy K. Donahue et al., Ready or Not? How Citizens and Public Officials Perceive Risk and Preparedness, 44 Am. Rev. Pub. Admin. 89S, 107S (2013). 
Second, past experience shows that both public and private actors are slow to anticipate evolving patterns of risk. For example, despite narratives of massive and destructive hurricane events in the first half of the 20th century, Hurricane Camille's landfall along the Mississippi-Alabama-Louisiana coast in 1969 shattered assumptions about the potential maximum size and power of a hurricane. ${ }^{88}$ In essence, an event like Camille had not been previously imagined and did not exist as a possibility in the public's consciousness. After the storm, the prevailing assumption became that Camille represented the upper limit of strength that a hurricane could carry, but Hurricane Andrew's destructive impact in Florida in 1992 demonstrated the fallacy of this assumption. With a new understanding provided by Andrew, preparedness efforts focused on a recurrence of a similarly-sized hurricane in a populated area. But neither experts nor the public imagined a situation in which multiple smaller storms would strike in relatively rapid sequence in the same general geographic area with total damage as large or larger than that of a single storm. Thus, when the cumulative impact of the eight hurricanes that made landfall in Florida and other Gulf Coast states in the 2004 and 2005 seasons vastly exceeded the damage that Andrew caused, the frame for understanding maximum impacts from hurricanes adjusted once again. ${ }^{89}$ The future is destined to reveal a new, currently unimagined hurricane event for which the public is not prepared.

Third, once public and private actors identify new or changed risks, they are slow to react to them. Many individuals and some firms have short economic horizons and do not choose investments that need a long time to earn returns. For example, a homeowner who expects to live in a home for only a few years before selling and relocating will correctly reason that the homeowner will not recoup a major investment in flood mitigation in the future sales price, and thus the mitigation investment is not cost-effective. ${ }^{90}$ Public officials behave similarly. For example, although officials knew of the possibility of a

88. In new construction and in areas previously devastated by hurricanes, stricter building codes proved effective following recent hurricanes. See, e.g., Mary Shanklin, Florida Building Codes Thwarted Hurricane Damage, Report Shows, OrLando SenTINEL (Mar. 20, 2018), http://www.orlandosentinel.com/classified/realestate/os-bz-flori da-home-construction-20180319-story.html [https://perma.cc/7DRP-W4LW]. Florida is the state with the largest number of mobile homes; according to the Manufacturing Housing Institute, 600,000 out of the 820,000 mobile homes in Florida are old models "not constructed to withstand hurricane-level winds." Danielle Paquette, Florida Has 828,000 Mobile Homes: Less Than a Third Were Built to Survive a Hurricane, WAsH. Post (Sep. 12, 2017), https://www.washingtonpost.com/news/wonk/wp/2017/09/12/flori da-has-828000-mobile-homes-only-half-are-insured/ [https://perma.cc/MXY7-WCAC].

89. See Billion-Dollar Weather, supra note 5 (listing Hurricanes Ivan, Wilma, Rita, Charley, Frances, Jeanne, Dennis, and Katrina as making landfall in Florida in 2004 and 2005).

90. Before the Great Recession, the national average home tenure was less than five years. As of 2016, the average tenure had risen, but only to 7.94 years. Kelsey Ramirez, ATTOM: Homeownership Tenure Hits Record High, HousingWIRE (Nov. 
hurricane disaster in New Orleans since at least Hurricane Betsy in 1965, it was more convenient for public officials to hope for good luck than construct more ambitious disaster response plans. ${ }^{91}$ In addition, normal election-cycle turnover in local government made it expedient for officeholders to defer investments in pre-event mitigation and punt such efforts to their successors-a cycle that repeated itself through the years. ${ }^{92}$ Thus, Hurricane Katrina was not so much a surprise as it was a failure to prepare for a known risk. ${ }^{93}$

Fourth, innumeracy compounds slow reaction to known events; in other words, individuals, firms, and regulators tend to make mathematically incorrect assumptions about the frequency of natural disaster events. The occurrence of the so-called 100-year flood does not mean, as many assume, that close to ninety-nine years of safety will follow the 100-year event; rather, the label means that there is a $1 \%$ chance that a flood of this size will happen in any given year. ${ }^{94}$ The misinterpretation of this common description of flood events leads some individuals and firms to underinvest in mitigation and sometimes to drop whatever insurance coverage they might already carry. Moreover, the descriptive benchmarks are often inaccurate; the data and science underlying these benchmarks often change, thereby causing the benchmarks - even if correctly interpreted-to under-predict the likelihood of flooding events. ${ }^{95}$ Another problem arises when individuals and firms make the rational choice to gather information about the magnitude of natural disaster risk because they are likely to find that experts disagree. This uncertainty discourages loss mitigation investment. Further, the optimism heuristic suggests that the actor will select the most favorable expert opinion to guide one's loss-reduction

17, 2016), https://www.housingwire.com/articles/38554-attom-homeownership-tenurehits-record-high [https://perma.cc/5CMT-FX9H].

91. See Mike Scott, Remembering Hurricane Betsy, a New Orleans Nightmare, Times-PicAYune (May 31, 2017), https://www.nola.com/300/2017/05/hurricane_betsy_ new_orleans_05312017.html [https://perma.cc/9BAM-DLNJ].

92. See Roger D. Congleton, The Story of Katrina: New Orleans and the Political Economy of Catastrophe, 127 Pub. CHOICE 17 (2006).

93. See Edward Richards, Hurricane Katrina-Was Flooding Really a Surprise?, LSU LAw CTr. (Aug. 26, 2010), https://sites.law.lsu.edu/coast/2010/08/hurricane-ka trina-was-flooding-really-a-surprise/ [https://perma.cc/3S5V-XUC8].

94. See FEMA Region 10, The 100 Year Flood Myth 2 (2011), available at https://raining.fema.gov/hiedu/docs/hazrm/handout\%203-5.pdf; Brian K. Sullivan, Misleading 100-Year Flood Label Doesn't Mean 99 Years of Safety, Claims J., (Apr. 25, 2016), https://www.claimsjournal.com/news/national/2016/04/25/270325.htm [https://perma.cc/CQ82-HM7S].

95. See Jen Schwartz, National Flood Insurance is Underwater Because of Outdated Science, ScI. Am. (Mar. 23, 2018), https://www.scientificamerican.com/article/ national-flood-insurance-is-underwater-because-of-outdated-science/ [https:// perma.cc/PK28-5FMB] (discussing outdated scientific assumptions on which NFIP is based). 
and mitigation strategy, when the best estimate would average the different expert opinions in some manner. ${ }^{96}$

Hurricane Harvey illustrates all of these heuristics in action. Until 2017, the prevailing assumption had been that hurricanes move on a linear path, dumping flood-producing rainfall along the way, with the consequences being a function of the intensity of the storm and the speed with which the system moves through a given area. What made Harvey unique-and what government officials and the public had not previously imagined-was a major hurricane stalling and slowly meandering back and forth in a defined area over a ninety-six-hour period. Yet although Harvey released over fifty inches of rain in some areas, these rainfall totals were not unprecedented. Tropical Storm Amelia in 1978, which prior to Harvey was the wettest tropical cyclone on record in the U.S., released forty-eight inches of rain in westcentral Texas. In 1979, Tropical Storm Claudette, which stalled for twenty-four hours in eastern Texas and western Louisiana, set a twenty-four-hour rainfall record at forty-two inches. Hurricane Easy released forty-five inches of rain on parts of Florida in $1950 .{ }^{97} \mathrm{Al}-$ though those data were available, government officials underestimated these risks and allowed development in areas with significant flood risk without requiring adequate mitigation planning. ${ }^{98}$ Thus, although experiences prior to 2017 with rainfall amounts in eastern Texas arguably made Harvey's consequences reasonably foreseeable, private and public actors undervalued the flood risk, underappreciated the evolving changes in the nature of the risk, and reacted slowly to the information available. ${ }^{99}$

96. See Harold Kunreuther, Mitigation and Insurance: Learning From Katrina, 604 Annals Am. Acad. Pol. \& Soc. Sci. 208, 211 (2006).

97. Peter Sousounis, How Unique Was Hurricane Harvey's Rainfall?, AIR (Aug. 31, 2017), http://www.air-worldwide.com/Blog/How-Unique-Was-Hurricane-Harvey \%E2\%80\%99s-Rainfall-/ [https://perma.cc/T4C9-MT5Z].

98. See Christopher Joyce, Scientists in Houston Tell a Story of Concrete, Rain and Destruction, NPR (Nov. 9, 2017, 7:53 AM), https://www.npr.org/2017/11/09/563016223/ exploring-why-hurricane-harvey-caused-houstons-worst-fooding [https://perma.cc/ 3SYQ-V659]; Vikas Bajaj et al., How Houston's Growth Created the Perfect Flood Conditions, N.Y. Times (Sept. 5, 2017), https://www.nytimes.com/interactive/2017/09/ 05/opinion/hurricane-harvey-flood-houston-development.html [https://perma.cc/ 33QA-2LNB].

99. This is the core of the dispute in criminal charges brought by the Harris County district attorney in August 2018 against a Houston chemical company that allegedly consciously disregarded the known risk of flooding to the reckless endangerment of surrounding populations. See Keri Blakinger et al., Arkema, CEO Indicted for 'Reckless' Chemical Release During Hurricane Harvey, Hous. Chron. (Aug. 3, 2018), https://www.houstonchronicle.com/news/houston-texas/houston/article/Arkema-CEO -indicted-for-reckless-chemical-13131012.php [https://perma.cc/8W8H-GHBS]. The premise of the indictment is controversial. See Rebecca Hersher, Case Alleges Chemical Companies Should Prepare For Unprecedented Storms, NPR (Aug. 30, 2018, 5:46 PM), https://www.npr.org/2018/08/30/638936124/lawsuit-alleges-chemical-companiesshould-prepare-for-unprecedented-storms [https://perma.cc/6X3J-5MPT]. 
Beyond the factors that cause individuals, firms, and regulators to underestimate risk and underinvest in prevention and mitigation, once one experiences catastrophic loss, it is difficult to sustain attention on addressing the risk and preparing for its next manifestation. Part of this is a function of short election cycles that make it difficult for government to engage in sustained planning efforts and implement programs requiring attention over time. Professors Jones and Baumgartner labeled this problem the inefficiency of attention-allocation-essentially a "bottleneck of agenda-setting" that "leads to severe inefficiencies in the allocation of attention to problems." ${ }^{100}$ With natural disasters, government actors assume or hope that many years will pass before the next catastrophe strikes, which conveniently rationalizes the actors' choices to divert their attention to other imminent issues. For example, at the time of Katrina, no hurricane had made landfall in New Orleans for fifty years, and at the time of Harvey, no major tropical rain event had occurred in Texas for thirty-nine years. Although such storms are equally probable in any given year, many people succumbed to the fallacy that a storm occurring in a given year meant that previous intervals between similar storms are likely to repeat in the future. ${ }^{101}$

The U.S. experience with volcanic activity provides an illustration of how these tendencies can play out in the insurance business. In May 1980, Mt. St. Helens erupted in the Cascade mountain range, destroying many homes and killing fifty-seven people, despite the fact that the eruption occurred in a remote area of southern Washington. ${ }^{102}$ In the most prominent insurance litigation following the eruption, insureds sued two insurance companies that denied the insureds' claims for the loss of their homes under their homeowners policies because the movement of Mt. St. Helens was an explosion excluded under their policies' terms. ${ }^{103}$ In a closely divided decision, the Washington Supreme Court reversed the trial court's entry of summary judgment for the insurers and remanded the case for additional fact findings. ${ }^{104}$ Interestingly, prior to March 1980, the insurance form in question contained a specific exclusion for loss "caused by . . . volcanic erup-

100. Bryan D. Jones \& Frank R. Baumgartner, The Politics of Attention: How Government Prioritizes Problems 277 (2005).

101. See generally Timothy Hall \& Kelly Hereid, The Frequency and Duration of U.S. Hurricane Droughts, 42 Geophysical Res. Letters 3482 (2015) (analyzing, in 2014 , the probability that a major hurricane would occur within the next year and end the nine-year run with no major landfall in the U.S.); Floods: Recurrence Intervals and 100-Year Floods (USGS), USGS, https://water.usgs.gov/edu/100yearflood.html (last updated Mar. 13, 2018) [https://perma.cc/KJ3P-JNDV].

102. See Mary Bagley, Mount St. Helens Eruption: Facts \& Information, LiveSCIENCE (Oct. 16, 2018), https://www.livescience.com/27553-mount-st-helens-eruption. html [https://perma.cc/8N6Y-KKJP].

103. Graham v. Public Employees Mut. Ins. Co., 656 P.2d 1077 (Wash. 1983) (en banc).

104. Id. at 1081. 
tion." 105 In an effort to simplify the form and ostensibly improve its readability, the insurers revised it to exclude "loss resulting directly or indirectly from: . . . 2. Earth Movement. Direct loss by ... explosion ... resulting from earth movement is covered." 106 Thus, the new form applicable to the May 1980 eruption had no explicit reference to volcanic eruption. In many situations, clearly drafted policy language will support a summary judgment in the insurer's favor, but in this Washington case, the court concluded that the applicability of the new language was a jury question. ${ }^{107}$

What is interesting about the Mt. St. Helens narrative is that insurance companies routinely take great care in drafting their policies, but the drafters of the policy at issue did not perceive volcanoes as a risk that merited specific mention in the exclusions. At the time of the policy redrafting, the last volcano to erupt in the lower forty-eight states was Lassen Peak in northern California in $1915 .{ }^{108}$ A number of small eruptions in active Alaska volcanoes, primarily located in remote areas on Alaska's peninsula, went almost unnoticed. ${ }^{109}$ Thus, by 1980, despite the existence of numerous volcanically active mountains in the western U.S., the risk of volcanic eruption was essentially out of mind, at least for insurance underwriting purposes. ${ }^{110}$ Further, since 1980, attention to the risk of volcanoes has not been persistent. ${ }^{111}$ For example, more than 150,000 people currently live on what are ancient mudflows of Mt. Rainier, and major highways, utilities, businesses, dams, and seaports will be in the path of these mudflows when they recur. ${ }^{112}$ Mt. Rainier last erupted in $1894-1895$, and scientists project a one-in-ten chance of a volcano producing a mudflow that would reach

105. Id. at 1079 .

106. Id.

107. Id. at 1079-80.

108. See The Eruption of Lassen Peak, NAT'L PARK Serv. (Feb. 28, 2015), https:// www.nps.gov/lavo/learn/nature/eruption_lassen_peak.htm [https://perma.cc/AZ83BVQN]. The 1915 eruption was the most powerful of a series of eruptions from 1914 to 1917. Lassen Peak is the largest of a group of thirty volcanoes that have erupted in that region over the last 300,000 years. Id.

109. See How Often Do Alaskan Volcanoes Erupt?, USGS at https://www.usgs.gov/ faqs/how-often-do-alaskan-volcanoes-erupt?qt-news_science_products=0\#qt-news_sci ence_products (last visited Dec. 10, 2018) [https://perma.cc/SAK9-9XK7].

110. See, e.g., Alan Blinder, It's Not Just Hawaii: The U.S. Has 169 Volcanoes That Could Erupt, N.Y. Times (May 14, 2018), https://www.nytimes.com/2018/05/14/us/usactive-volcanoes-hawaii.html [https://perma.cc/RX2G-SCGE] ("The United States Geological Survey counts 169 potentially active volcanoes in the country . . ..”).

111. The recent eruption of Kilauea in Hawai'i Volcanoes National Park does not appear to have sparked significant reflection on significant risks in the Cascade Range. For more on the Hawai'i volcanoes, see Park Closure Information \& FAQ, Hawai'i Volcanoes National Park, NAT'L PARK SERV. https://web.archive.org/web/ 20180712121325/https://www.nps.gov/havo/2018-closure.htm (last visited Dec. 10, 2018) [https://perma.cc/9AJN-3C98].

112. Carolyn L. Driedger \& William E. Scott, Mount Rainier-Learning TO Live With Volcanic Risk, USGS (2002), available at https://pubs.usgs.gov/fs/ 2002/0034/report.pdf. 
the Puget Sound lowland during an average human lifespan. ${ }^{113}$ In short, despite ample evidence of the consequences of ignoring natural disaster risk, individuals, firms, and regulators routinely underinvest in preventing and limiting those consequences.

Notwithstanding the awesome forces that produce hurricanes, much can be done to prevent loss and mitigate consequences. The most obvious and effective way to reduce any kind of natural disaster risk is not to live or operate a business in a geographic area prone to such disasters. Today, population patterns are trending in the other direction. The infrequency of natural disasters, the unpredictability of where impacts will occur, and the overall quality of living in areas at greatest risk combine to attract residents and businesses to these areas. This is especially true with respect to coastal living where the hurricane risk is acute. Cultural and social factors, employment, expense, and inertia are compelling reasons why relocation is an unattractive option for many individuals and businesses. Although it may be reasonable to predict that the increasing risk of hurricane damage on and near the coasts may reduce the rate of growth in-or at least the number of people or businesses choosing to reside in-these locations, under any reasonable scenario the assets and people exposed in these locations will remain massive. ${ }^{114}$ New Orleans is an example of this. Despite the significant population declines in the city after Hurricane Katrina, the city and its exposures remain large. ${ }^{115}$

Another option is simply to spend more on mitigation. ${ }^{116}$ Hurricanes predominantly produce two kinds of damage-wind and flood. ${ }^{117}$ For each peril, many opportunities to deploy mitigation strategies exist. ${ }^{118}$ Wind damage can be ameliorated through: structural

113. Carolyn L. Driedger \& William E. Scott, Mount Rainier - Living Safely With a Volcano in Your Backyard, GeOLOGY.COM, https:/geology.com/usgs/rainier/ (last visited Dec. 10, 2018) [https://perma.cc/UZD5-CQS9].

114. Migration away from the coasts will eventually be necessary due to water inundation. See Mathew E. Hauer et al., Millions Projected to Be at Risk From SeaLevel Rise in the Continental United States, 6 NATURe 691 (2016) (forecasting that 13.1 million Americans are at risk of needing to migrate to inland areas to escape water inundation); Kendra Pierre-Louis, As Sea Levels Rise, Where Will All the People Go?, Popular ScI. (Apr. 17, 2017), https://www.popsci.com/sea-level-rise-refugee \#page-3 [https://perma.cc/86SP-2NDE].

115. The population of New Orleans fell from 484,674 in April 2000 to an estimated 230,172 in July 2006 (after Katrina), halving the city's population. By July 2015, the population had increased to 386,617 , approximately $20 \%$ lower than it was pre-Katrina. Allison Plyer, Facts for Features: Katrina Impact, The Data Ctr. (Aug. 26, 2016), https://www.datacenterresearch.org/data-resources/katrina/facts-for-impact/ [https://perma.cc/2GCN-7NKL].

116. Barnosky, supra note 55.

117. Aguado \& Burt, supra note 7, at 370-74.

118. Earthquakes are susceptible to analogous arrays of mitigation and prevention strategies. See generally FEMA, Homebuilders' Guide to EArthouAKe ResisTANT Design AND Construction (2006), available at https://www.fema.gov/medialibrary-data/20130726-1535-20490-7368/fema232.pdf. 
bracing, ${ }^{119}$ straps and clips, ${ }^{120}$ anchor bolts, ${ }^{121}$ impact-resistant glass, ${ }^{122}$ solid roofing surfaces on commercial buildings, ${ }^{123}$ reinforced pedestrian and garage doors, ${ }^{124}$ hurricane shutters, ${ }^{125}$ interlocking roof shingles and improved nailing patterns, ${ }^{126}$ special anchors for mobile homes, ${ }^{127}$ foundation designs that resist lateral wind and water forces ${ }^{128}$ continuous steel bracing for chimneys, ${ }^{129}$ and tree pruning. ${ }^{130}$ Construction and zoning codes that require these measures on new construction or retrofitting upon remodeling are key components of these risk management strategies. ${ }^{131}$

119. See James Glave, Hurricane Safety Lessons Learned From Past Storms, THIS Old House, https://www.thisoldhouse.com/ideas/hurricane-safety-lessons-learnedpast-storms (last visited Dec. 10, 2018) [https://perma.cc/M7H5-WRW8].

120. See Ernest Beck, Tying Down the Roof, N.Y. Times (Sept. 1, 2005), https:// www.nytimes.com/2005/09/01/garden/tying-down-the-roof.html?mtrref=www.google. com [https://perma.cc/5AH4-WST7] (these small structural bracing devices are made of galvanized steel and reinforce house joints, as well as anchor the roof to the house, better than nails can).

121. See John W. van de Lindt et al., Performance of Wood-Frame Structures During Hurricane Katrina, 21 J. Performance Constructed Facilities 108, 115 (recommending the use of proper anchor bolts with other straps and ties).

122. See, e.g., Impact-Resistant Hurricane Windows and Patio Doors, Pella Corp., http://www.pella.com/features-options/hurricaneshield/ [https://perma.cc/TF7D-7E HS] (advertising impact-resistant windows).

123. See Joshua Kneifel et al., Nat'l Inst. of Standards \& Tech., Economid Analysis of Restricting Aggregate-Surfaced Roofing Systems in TorNADO-Prone Areas OF THE U.S. 1 (2016), available at https://nvlpubs.nist.gov/ nistpubs/TechnicalNotes/NIST.TN.1930.pdf.

124. See FEMA, Protecting Your Property From Wind, available at http:// www.crh.noaa.gov/Image/fwd/pdf/swa/FEMA_Protecting_Business_Wind.pdf (noting that garage doors and double entry doors are especially susceptible to high winds and may be a weak point).

125. See FEMA, Protect Windows And Doors With Covers (2017), available at https://www.fema.gov/media-library-data/20130726-1627-20490-8875/how2017_how 2029_protect_windows_doors_4_11.pdf.

126. See FEMA, Mitigation Ideas: A Resource for Reducing Risk to NatuRAL Hazards 46 (2013), available at https://www.fema.gov/media-library-data/ 20130726-1904-25045-2423/fema_mitigation_ideas_final_01252013.pdf.

127. See Joseph B. Treaster \& Henry Fountain, Considered Vulnerable, Mobile Homes Are Battered but Largely Intact, N.Y. Times (Sept. 14, 2017), https:// www.nytimes.com/2017/09/14/us/mobile-homes-florida-irma.html [https://perma.cc/ 7C39-VJ88] (noting that stricter mobile home regulations reduced damage to mobile homes during Hurricane Irma). These anchors may be required to obtain insurance. Id.

128. See FEMA, Recommended Residential Construction for Coastal AreAs: Building on Strong and SAFe Foundations 2-1-5-5 (2d ed. 2009).

129. See FEMA, supra note 126, at 46 (suggesting "new masonry chimneys greater than 6 feet above a roof to have continuous reinforced steel bracing").

130. See FeMA, Remove Trees and Potential Windborne Missiles (2011), available at https://www.fema.gov/media-library-data/20130726-1627-20490-3107/ how2020_trees_missiles_4_11.pdf.

131. Houston, Texas is sometimes mentioned as the only large city in the U.S. to lack zoning regulations. See Bill Schadewald, The Only Major U.S. City Without Zoning, Hous. Bus. J. (Apr. 9, 2006), https://www.bizjournals.com/houston/stories/2006/ 04/10/editorial1.html [https://perma.cc/FZF9-HLVU]; Loren Steffy, Lack of Zoning Has Paid off for Houston, Hous. CHron. (May 28, 2008), https://www.chron.com/ 
With respect to flooding-many of these techniques are suitable whether the risk is hurricane-related or river and surface-water related-loss can be prevented through: increased freeboard requirements, which set the number of feet above flood elevation at which structures must be built, ${ }^{132}$ tie-downs for propane tanks, ${ }^{133}$ prohibitions on first-floor enclosed space in flood-plain and coastal areas to enable storm surge to flow through the first floor opening instead of overwhelming the entire structure or destroying the first-floor living space, ${ }^{134}$ ensuring that appliances and heating and cooling units are above potential flood levels, ${ }^{135}$ detention basin designs, which are lands set aside to collect water that would otherwise flood property, ${ }^{136}$

business/steffy/article/Lack-of-zoning-has-paid-off-for-Houston-1678292.php [https:// perma.cc/JK9N-W3QF]. Houston, however, has many regulations that function similarly to zoning rules despite the absence of codification. Critics argue that these rules are not part of a comprehensive plan or strategy, which is typical of most zoning codes. See Ryan Holeywell, Forget What You've Heard, Houston Really Does Have Zoning (Sort of), RicE KINDER, (Sept. 8, 2015), https://kinder.rice.edu/2015/09/08/for get-what-youve-heard-houston-really-does-have-zoning-sort-of/ [https://perma.cc/ CUZ3-3ZGM]. Further, whether this regulatory framework (or vacuum, depending on one's point of view) increased the flood damage from Harvey is hotly contested. See Aaron Davis et al., Houston's 'Wild West' Growth: How the City's Development May Have Contributed to Devastating Flooding, WAsH. Post (Aug. 29, 2017), https:// www.washingtonpost.com/graphics/2017/investigations/harvey-urban-planning/?utm term=.ac8884df1776 [https://perma.cc/4F35-X2RZ]. Scott Beyer, Don't Blame Houston's Lack of Zoning for Harvey Flooding, THE Hill (Sept. 3, 2017), https:// thehill.com/blogs/pundits-blog/state-local-politics/349021-opinion-dont-blame-hous tons-lack-of-zoning-laws-for [https://perma.cc/JV89-AXQD] (Jim Blackburn of Rice University said that Houston's flooding is not a zoning-related problem, referencing clay composition of soil, which impedes water absorption, that no amount of zoning could alleviate). Irvin Dawid, The Culprit of Houston Flooding: Sprawl, Not Lack of Zoning, Planetizen (Sept. 4, 2017, 7:00 AM), https://www.planetizen.com/node/ 94613/culprit-houston-flooding-sprawl-not-lack-zoning [https://perma.cc/XG78N6LW] (quoting Professor John Jacob, Texas A\&M scientist, regarding loss of waterabsorbing freshwater wetlands due to urban sprawl).

132. See Freeboard, FEMA, https://www.fema.gov/freeboard (last visited June 28, 2018) [https://perma.cc/58WF-GNPC].

133. See Propane Safety and Hurricanes, Propane Educ. \& Res. Council, available at https://www.propane.com/uploadedFiles/PropaneMain/Propane/Residential/Safety/Hurricane_Safety_Instructions/propane-safety-and-hurricanes.pdf [https:// perma.cc/MDG6-6XHJ] (noting to ensure that "[i]n flood zone areas, ... large aboveground and underground propane tanks are anchored securely to avoid potentially dangerous situations").

134. See David Ovalle, Keys Homes, Battered but Standing, May Be a Model for Reducing Damage in Florida, Miami Herald (Sept. 14, 2017), https://www.miamiher ald.com/news/weather/hurricane/article173408496.html [https://perma.cc/Z5HPDU8Y] ("The ground-floor garage - designed to give way to surge - was an unmitigated mess, along with the docks and yard. But the structure stood strong, the upper floor where people live untouched inside.").

135. See FEMA, Homeowner's Guide to Retrofitting: Six Ways to Protect Your HOMe FrOM Flooding 9-1-9-7 (3d ed. 2014), available at https://www. fema.gov/media-library-data/1404148604102-f210b5e43aba0fb393443fe7ae9cd953/FE MA_P-312.pdf.

136. See Stormwater Detention: How It Works, Harris CTy. Flood Control DIsT., https://www.hcfcd.org/flooding-floodplains/stormwater-detention-how-it- 
and water runoff management, which directs the path of excess water. ${ }^{137}$ These techniques will not prevent wind-driven water or a flood from occurring, but each may reduce the size of the losses when they occur. Although Hurricane Michael destroyed most of Mexico Beach, Florida in October 2018, relatively low-cost reinforcements saved the few homes that withstood the storm. ${ }^{138}$

Numerous challenges exist to increasing prevention and mitigation. Investments in construction, buildings, and infrastructure to minimize loss in the event of a disaster are often low priority on account of the previously-described heuristic. ${ }^{139}$ Despite data consistently demonstrating strong returns on individual or firm investments in prevention and mitigation, retrofitting is expensive, and installing loss-reducing features in new construction can add significantly to construction cost. ${ }^{140}$ Uncertainty is a factor; the extent to which such investments will actually result in loss reduction is unknown until the hardened construction and infrastructure actually confronts a disaster. This uncertainty often deters the investment. ${ }^{141}$ Many individuals and firms find it difficult, or are sometimes unable, to translate short-term costs into long-term benefits. This uncertainty tends to result in underinvestment in loss mitigation and leads to the purchase of insurance. ${ }^{142}$

Government actions and incentives can counter the tendency of private actors to underinvest in loss mitigation. Government has built, and owns, much of the nation's infrastructure, and thus public officials

works/ (last visited June 28, 2018) [https://perma.cc/C6CV-85CA] (describing the process of using excavated water storage areas "to offset or mitigate the negative effect development may have on flooding (due to covering up soil with buildings and concrete and speeding up the rate water runs off an area)").

137. See Ian Bogost, Houston's Flood Is a Design Problem, Atlantic (Aug. 28, 2017), https://www.theatlantic.com/technology/archive/2017/08/why-cities-flood/ 538251/ [https://perma.cc/YJ46-J3KC] (explaining that impervious surfaces are to blame for flooding issues within cities and that stormwater management is the solution to remove that rainfall from the city, though the process may not be ideal).

138. See Patricia Sullivan et al., Houses Intact After Hurricane Michael Were Often Saved by Low-Cost Reinforcements, WAsH. Post (Oct. 17, 2018), https://www.wash ingtonpost.com/politics/panhandle-houses-intact-after-michael-were-often-saved-bylow-cost-reinforcements/2018/10/17/d3ca97c0-d152-11e8-b2d2-f397227b43f0_story. html?utm_term=.adfda46015d9 [https://perma.cc/DT47-J29G].

139. See supra note 86 and accompanying text.

140. By one calculation, the cost to retrofit a home for hurricane preparedness is approximately $\$ 30,000$. See Dan Bigman, What Would It Cost to Make Your House Truly Storm Proof? A Start Shopping List., Forbes (Oct. 29, 2012, 4:26 PM), https:// www.forbes.com/sites/danbigman/2012/10/29/what-would-it-cost-to-make-your-housetruly-storm-proof-a-starter-shopping-list/\#6d48e98360a7 [https://perma.cc/2ETF-DF $\mathrm{YH}]$. For detailed analysis of costs and benefits of particular mitigation strategies, see Nat'l Inst. of Building Sci., Natural Hazard Mitigation Saves: 2017 InTERIM REPORT (2017), available at http://www.wbdg.org/files/pdfs/MS2_2017Interim \%20Report.pdf.

141. Id. at 10.

142. See Eric Neumayer et al., The Political Economy of Natural Disaster Damage, 24 Global Envtl. Change 8, 9 (2014). 
have the authority to specify the extent the government invests-at taxpayer expense - in hardening these assets. As for privately owned assets, government can influence or control these through zoning regulations and building codes, rules affecting where private actors can locate their residences and businesses, and rules that specify the extent to which government requires loss-mitigation investments in new construction or retrofits. ${ }^{143}$ The federal government can encourage private investment through tax incentives, can provide direct funding for an array of investments - either fully or on a cost-sharing basisand can create other incentives to encourage states and localities to adopt additional pre-loss mitigation strategies. ${ }^{144}$ Yet just as the private sector is likely to underinvest in prevention and mitigation, government has a tendency to do so as well. Government efforts to require private investments are typically unpopular, and investing public revenues on behalf of private actors is likely to be unpopular with taxpayers. Public officials tend to prefer short-term political support over the negative consequences attached to unpopular decisions that produce under-appreciated, long-term benefits. ${ }^{145}$

To summarize, although many options exist for making cost-effective, benefit-optimizing investments in prevention and mitigation, the impediments to pursuing them appear, thus far, nearly impossible to overcome. Thus, in the aftermath of the 2005 hurricane season, taxpayers paid more in disaster relief than the combined sum of windrelated losses under private insurance and flood-insured losses under the National Flood Insurance Program. ${ }^{146}$ Yet the federal government's pre-disaster mitigation spending decreased from $\$ 157$ million in 2005 to $\$ 19$ million in 2014, despite evidence that such expenditures reduce post-loss costs by many multiples of the amount of the investment. $^{147}$

143. $I d$.

144. Barnosky, supra note 55.

145. $I d$.

146. Erwann Michel-Kerjan \& Jacoueline Volkman-Wise, The Risk of Ever-Growing Disaster Relief Expectations 3 (2011), available at http:/cite seerx.ist.psu.edu/viewdoc/download?doi=10.1.1.420.5131\&rep=rep1\&type=pdf.

147. It Pays to Prepare for Natural Disasters, PEW (May 8, 2017), http://www.pew trusts.org/en/research-and-analysis/fact-sheets/2017/05/it-pays-to-prepare-for-naturaldisasters [https://perma.cc/NV3Y-YL7K]. One recent study produced an estimate that the net present value of $\$ 1$ of disaster preparedness correlates with $\$ 15$ in reduction of future damage, discounted to present value. See Andrew Healy \& Neil Malhortra, Myopic Voters and Natural Disaster Policy, 103 Am. Pol. ScI. Rev. 387, 396 (2009). See also Cheney M. Shreve \& Ian Kelman, Does Mitigation Save? Reviewing CostBenefit Analyses of Disaster Risk Reduction, 10 InT'L J. Disaster Risk Reduction 213 (2014) (reviewing literature that mitigation saves lives, the environment, and money in the U.S. and globally). 


\section{B. Limitations of Private Insurance}

Insurance literature often refers to natural disasters as uninsurable risks, ${ }^{148}$ but the description uninsurable is somewhat misleading because insurance for many kinds of natural disasters is, in fact, available. Describing the insurability of hurricane and other natural disaster risk as difficult is unquestionably correct. ${ }^{149}$ The primary characteristics of difficult risks are twofold. ${ }^{150}$ First, they resist diversification. When a risk pool consists of perfectly or highly correlated risksmeaning that a very large percentage of the risk pool is certainly or likely to suffer loss when a covered peril happens-loss-spreading distribution of risk is ineffective, and the insurance mechanism will fail. Second, difficult risks are ambiguous in that both their frequency and their consequences are difficult to predict. When measuring the risk is complex and prone to inaccuracy, insurers tend not to supply the product or are willing to do so only if the premiums are high enough to cover the insurer's uncertainty risk. Thus, difficult risks can lead to an absence of supply and consequent market failure.

The market for flood insurance is a classic example of a difficult risk causing market failure. Early property insurance and accidental loss policies covered flood damage, but the industry's interest in selling the product ceased in the wake of serious flood loss events in the early 20th century. ${ }^{151}$ Multiple reasons led to insurers exiting this market. Insurers lacked reliable flood data, which prevented accurate product pricing, which in turn led to product scarcity and high premiums where coverage existed. ${ }^{152}$ Insurers did not discover an effective way to deal with severe adverse selection; those who needed the coverage were most likely to purchase it, which led to higher premiums that dampened demand and increased the amount of uninsured risk. ${ }^{153}$ The highly correlated nature of flood risk, the inability of insurers to adequately diversify the risk, and the unevenness of the frequency of flood events over periods of time essentially overwhelmed the ability

148. See, e.g., National Flood Insurance Program, NAT'L Ass'N for Ins. CommisSIONERS, https://www.naic.org/cipr_topics/topic_nfip.htm (last updated Sept. 25, 2018) [https://perma.cc/5RN5-MP2W]; Dwight M. Jaffee \& Thomas Russell, Catastrophe Insurance, Capital Markets, and Uninsurable Risks, 64 J. Risk \& INs. 205, 206 (1997) (catastrophes are considered an "uninsurable risk").

149. See Lucien J. Dhooge, A Previously Unimaginable Risk Potential: September 11 and the Insurance Industry, 40 Am. Bus. L.J. 687, 774 (2003).

150. See Robert H. Jerry, II \& Steven E. Roberts, Regulating the Business of Insurance: Federalism in an Age of Difficult Risk, 41 WAKE Forest L. REv. 835, 842-46 (2006). A third characteristic is that demand for insurance for difficult risks is low due to the heuristics discussed elsewhere in this article. Id. at 845-46. See Kunreuther, supra note 86.

151. See Adam F. Scales, A Nation of Policyholders: Governmental and Market Failure in Flood Insurance, 26 Miss. C.L. REv. 3, 6 (2007) (discussing the early history of flood insurance).

152. Id. at 8 .

153. Id. at $8-9$. 
of insurers to cover the risk. ${ }^{154}$ When Hurricane Betsy highlighted that most homes in the Gulf region were at risk for catastrophic flooding damage in hurricanes but did not have flood insurance, ${ }^{155}$ the absence of a functional private market and an evolving sense of the proper governmental role in disaster responsibility led to the enactment of the National Flood Insurance Program ("NFIP") in 1968. ${ }^{156}$

Although Congress expected the NFIP to restore the private flood insurance market, this intervention failed, and subsequent attempts to improve that outcome have not succeeded. ${ }^{157}$ Three problems with the current framework are particularly salient. First, persistent confusion exists among consumers about what policies need to be purchased. In the face of this confusion, many consumers fail to purchase any coverage at all. ${ }^{158}$ For example, many policyholders incorrectly assume that coverage for windstorm, which is included in most-but not all-homeowners policies, brings hurricane losses within the coverage. But the standard policy covers wind loss and excludes flood loss. In the context of hurricanes, wind and water can act either independently or concurrently to cause loss. Thus, insurers treat losses caused by storm surge flooding as excluded flood loss, while losses caused by wind-driven rain intrusion (for example, through broken windows or a wind-damaged roof) are covered. ${ }^{159}$ Many property insurance policies contain anti-concurrent cause provisions, which provide that if a loss is caused by a combination of a covered cause (e.g., wind) and an excluded cause (e.g., flood), the loss is not covered. ${ }^{160}$ If these provisions are enforced, ${ }^{161}$ they narrow coverage. Moreover,

154. See Patricia Born \& W. Kip Viscusi, The Catastrophic Effects of Natural Disasters on Insurance Markets, 33 J. Risk UnCERTAINTY 55 (2006).

155. See Logan Strother, The National Flood Insurance Program: A Case Study in Policy Failure, Reform, and Retrenchment, 46 Policy Studies J. 1, 8 (2016) (discussing the history of NFIP). Hurricane Betsy killed seventy-six and caused more than $\$ 10$ billion in damage (in current dollars). See Mike Scott, Remembering Hurricane Betsy, a New Orleans Nightmare, Times-PICAYUne (Dec. 6, 2017), https://www.nola.com/ 300/2017/05/hurricane_betsy_new_orleans_05312017.html [https://perma.cc/X93BDEMB].

156. See Strother, supra note 155 , at $8-9$.

157. Id. at $8-10$.

158. See Press Release, Insurance Information Institute, Hurricane Harvey Coverage: Key Differences Between Homeowners Insurance and Flood Insurance (Aug. 30, 2017), https://www.iii.org/press-release/hurricane-harvey-insurance-coverage-key-dif ferences-between-homeowners-insurance-and-flood-insurance-090617 [https://perma. cc/D4GJ-CP2V] (reporting that over $40 \%$ of homeowners think that standard homeowner's insurance covers flood damage caused by heavy rain).

159. Jennifer Walker, Storm Event: When Multiple Water Perils Intersect, AмWINS GrP., INC. (Apr. 24, 2016), http://www.amwins.com/insights/article/storm-event-whenmultiple-water-perils-intersect_4-18 [https://perma.cc/5XAW-ED2F].

160. See Dale Gilsinger, Validity, Construction, and Application of Anticoncurrent Causation (ACC) Clauses in Insurance Policies, 37 A.L.R.6th 657 (2008).

161. Some courts have held that these clauses violate public policy and are unenforceable. See, e.g., Safeco Ins. Co. of Am. v. Hirschmann, 773 P.2d 413 (Wash. 1989); Murray v. State Farm Fire \& Cas. Co. 509 S.E.2d 1 (W. Va. 1998), Other courts have 
property insurance policies sold in coastal areas often exclude coverage for wind damage. In Texas, for example, after Hurricane Celia in 1970, many insurers decided to cease selling homeowners insurance in the coastal communities. The legislature responded in 1971 by creating the Texas Windstorm Insurance Association that offers, via a consortium consisting of every property insurer in the state, specially rated windstorm coverage in fourteen coastal counties and part of Harris County-but not Houston. ${ }^{162}$ In other words, whether coverage exists for hurricane-caused wind damage in a homeowners policy varies with the product and the locale in which it is sold, which adds further confusion to the market.

Second, when coverage exists, policy limits and deductibles often fall short of what is needed to repair or replace damaged property without substantial out-of-pocket policyholder contribution. Although replacement cost coverage has been the norm for decades, if a policyholder fails to insure property for at least $80 \%$ of the replacement cost, a loss will be adjusted at actual cash value, which means depreciation is offset from replacement cost when calculating the proceeds to be paid. ${ }^{163}$ The older the property, the larger the offset and resulting coverage gap will be. This gap, which is called a coinsurance penalty, tends to arise in times of appreciating construction costs when insureds do not periodically review the relation between their policy limits and asset values. Additionally, in nineteen states and the District of Columbia, insurers are authorized to use percentage deductibles for hurricane losses, as opposed to the usual first-dollar deductible applicable to other losses. ${ }^{164}$ The hurricane deductible, like any deductible, has the effect of taking small losses - up to the amount of the deductible-outside the coverage. The insured selects the size of the deductible from a menu of options, with larger deductibles producing lower premiums. The hurricane deductible, however, is typically larger, usually varying between $1 \%$ and $5 \%$ of the replacement cost of the property, which increases out-of-pocket expenses for the policyholder. Moreover, in the aftermath of catastrophes, insurers have historically responded by limiting their exposure in catastropheprone areas through stricter underwriting, higher deductibles, and lower coverage limits. ${ }^{165}$

upheld them. See, e.g., State Farm Fire \& Cas. Co. v. Bongen, 925 P.2d 1042 (Alaska 1996); Bao v. Liberty Mut. Fire Ins. Co., 535 F.Supp.2d 532 (D. Md. 2008).

162. See U.S. Gov't Accountability Off., GAO-08-7, Natural Disasters: Public Policy Options for Changing the Federal Role in Natural CatasTROPHE INSURANCE 67-69 (2007) [hereinafter GAO-08-7].

163. JERRY \& RichmOND, supra note 66, at 549-53.

164. See Background on: Hurricane and Windstorm Deductibles, Ins. InFo. Inst., https://www.iii.org/article/background-on-hurricane-and-windstorm-deductibles (last visited June 25, 2018) [https://perma.cc/G6DG-CP4U].

165. See Robert Meyers, Impact of Natural Catastrophes on Insurance Market, Ins. J. (Nov. 20, 2017), https://www.insurancejournal.com/magazines/mag-features/2017/ 11/20/471204.htm [https://perma.cc/EM4V-YXKQ] (in the aftermath of 2017 hurri- 
Third, when coverage is available, homeowners and renters frequently fail to purchase it. Some simply lack an understanding of the importance of insurance and do not comprehend the potential consequences of not having it; consequently, they do not purchase it. ${ }^{166}$ Some households cannot afford it. ${ }^{167}$ Some own their homes without an encumbrance from a lender or mortgagee; without a requirement from a lender that they purchase insurance, they choose not to do so. ${ }^{168}$ People who inherit unencumbered property sometimes fail to consider the insurance implications of the inheritance. Some people, aware of Congress's proclivity to appropriate funds for disaster relief and recovery, incorrectly assume that these ex post funds provide adequate protection from the financial consequences of hurricanes and therefore do not purchase insurance.

These limitations translate, even with significant federal intervention in the flood insurance market, to significant coverage gaps. According to the General Accountability Office ("GAO"), approximately $41 \%$ of homes that sustained severe damage from the 2005 hurricanes were uninsured or underinsured, and almost $38 \%$ of owner-occupied homes that sustained severe wind damage lacked insurance against wind loss. ${ }^{169}$ In the northeast, where Hurricane Sandy struck, only $15-25 \%$ of at-risk properties were insured for flood loss. ${ }^{170}$ The same was true for the 2017 hurricanes: In Hurricane Harvey, fewer than $20 \%$ of victims had flood insurance. ${ }^{171}$ In Hurricane Maria, roughly $50 \%$ of the homes and structures in Puerto Rico were uninsured against wind damage. ${ }^{172}$ According to a McKinsey study, in

canes, "there will likely be an immediate increase in rates followed by higher deductibles and limitations on coverage in the longer term"); TOWERS WATSON, Hurricane Katrina: Analysis of the Impact on the Insurance Industry (2005), available at https://biotech.law.lsu.edu/blog/impact-of-hurricane-katrina-onthe-insurance-industry-towers-watson.pdf (describing the impact of Hurricane Katrina on insurance rates and availability).

166. See Howard C. Kunreuther et al., Insurance and Behavioral EcoNOMICS (2013).

167. Id.

168. In the Flood Disaster Protection Act of 1973, Pub. L. 93-234, 87 Stat. 975 (1973), Congress required federally regulated mortgage lenders to ensure that borrowers in areas designated as flood risks purchase flood insurance and keep it in force for the duration of the loan. Id. $\S 4012$ a.

169. See GAO-08-7, supra note 162, at 25.

170. Anita Lee, Sandy Catches Northeasterners Without Flood Coverage, Sun HerALD (Nov. 2, 2012, 5:55 PM), https://weather.com/news/news/sandy-northeasternersno-insurance-201211 [https://perma.cc/ZX77-VEP4].

171. See Long, supra note 19.

172. Leslie Scism \& Nicole Friedman, Hurricane Maria Exposes a Common Problem for Puerto Rico Homeowners: No Insurance, Wall St. J. (Sept. 20, 2017, 4:51 PM), https://www.wsj.com/articles/hurricane-maria-exposes-a-common-problem-forpuerto-rico-homeowners-no-insurance-1505940660 [https://perma.cc/UAW5-TSZ5]. The insurance gap is a global problem. See Thomas Holzheu \& Ginger Turner, Closing the Natural Catastrophe Protection Gap, Swiss RE Inst. (Mar. 16, 2018), https:// www.swissre.com/institute/research/topics-and-risk-dialogues/natcat-and-climate/Clos ing-the-natural-catastrophe-protection-gap.html [https://perma.cc/SD8M-AEVC]. 
the counties most affected by Harvey, Maria, and Irma, approximately $80 \%$ of Texas homeowners, $60 \%$ of Florida homeowners, and $99 \%$ of Puerto Rican homeowners did not have flood insurance. ${ }^{173}$

The failure of the private flood insurance market led to the NFIP and the significant federal presence in that market, but the insurance business may have matured in ways that now make it possible for the private market to generate a viable flood insurance product. In fact, in recent years, some insurance companies have entered the flood insurance market, and others have expressed interest in doing so. ${ }^{174}$ Currently, the private residential flood insurance market is smallprobably $3.5-4.5 \%$ of all primary residential flood policies presently in force ${ }^{175}$ - and approximately $40 \%$ of these policies have been written in Puerto Rico and Florida. ${ }^{176}$ Most private flood policies apply to commercial properties, but the residential market is a significant portion of all private flood insurance policies in force. ${ }^{177}$

Whether expanding private coverage is good for consumers is controversial. The main critique is that private insurers will write coverage on lower-risk properties that the NFIP has overpriced, thereby leaving the NFIP with higher-risk properties. This will drive the cost of NFIP-underwritten insurance higher and create access problems for those unable to afford the higher premiums. ${ }^{178}$ On the other hand, private market advocates contend that any portion of the NFIP program's portfolio that can be handled in the private sector would produce a net positive by lowering taxpayer exposure for the current deficits in the NFIP program. ${ }^{179}$ Also, to the extent that the private market expands, better products with superior coverage more precisely tailored to the needs of particular categories will emerge. Skep-

173. Erwann Michel-Kerjan \& Giambattista Taglioni, McKinsey \& Co., Insurance Hurricanes: Perspectives, Gaps, and Opportunities After 20179 (2017), available at https://www.mckinsey.com/ /media/McKinsey/Industries/Financial $\% 20$ Services/Our\%20Insights/Insuring \%20hurricanes \%20Perspectives \%20gaps \% 20 and \%20opportunities\%20after\%202017/Insuring-hurricanes-Perspectives-gaps-andopportunities-after-2017.ashx.

174. A careful review and informative discussion of the private residential flood insurance market is contained in CAROLyn Kousky et al., Wharton Risk MgMt. \& Decision Processes Ctr., The Emerging Private Residential Flood Insurance Market in the United States (2018).

175. Id. at 2. S\&P Global Market Intelligence data indicate that the private market grew $50 \%$ in 2017 over the prior year, with private policies now representing almost $15 \%$ of all national flood premiums. Ray Lehman, Private Flood Insurance Market Is Getting Bigger, More Competitive, Less Profitable, Ins. J., (Mar. 8, 2018), https:// www.insurancejournal.com/blogs/right-street/2018/03/18/483689.htm [https://perma.cc/ 7JGQ-4DXC].

176. KOUSKY ET AL., supra note 174, at 2.

177. Id. at 4.

178. Id.; see also Daniel Schwarcz, How to Fix America's Broken Flood Insurance Scheme, WAsh. Post (Sept. 7, 2017), https://www.washingtonpost.com/opinions/howto-fix-americas-broken-flood-insurance-scheme/2017/09/07/7cb5d2fe-93d9-11e7-aace04b862b2b3f3_story.html?utm_term=.97971cc017e8 [https://perma.cc/RFG8-7TGN].

179. KousKY ET AL., supra note 174, at 4. 
tics, however, predict that insurers will be more likely to offer thinner coverage that generates less ex post compensation, and to cancel policies or increase rates after policyholders file a claim. ${ }^{180}$ Skeptics also express concern that a more robust private market, as it deflates NFIP program revenues, will undermine NFIP flood mapping and mitigation programs. ${ }^{181}$ Even ardent advocates of a more robust private flood insurance market concede that the private market will be unable to underwrite most flood risk in the U.S. due to concentrated exposures and correlated losses. ${ }^{182}$ Thus, the prospect of private market expansion is essentially a question of whether public and private catastrophe insurance can co-exist, and whether an expanded private presence will add stability to the overall market.

A different approach to reforming the private market borrows from the regulatory tool-long a major feature of health insurance-of requiring certain coverages for products sold in the private market. For natural disaster risk, the government could mandate that all homeowners insurance policies provide (and consumers pay for) coverage-i.e., that homeowners insurance becomes essentially an all-perils policy. ${ }^{183}$ Significant public resistance to insurance mandates in the health insurance sector suggests that such a major reform of homeowners insurance would encounter substantial political resistance. ${ }^{184}$ A difference exists between mandating coverage terms and mandating that consumers purchase policies, the latter of which has been a major flash point in the ongoing debate over the Affordable Care Act. But because the purchase of homeowners insurance is required by lenders on mortgaged property, and because for most consumers self-insuring personal residences is not an option, mandated coverage of natural disaster risk in homeowners policies would increase premium levels, likely resulting in pushback from the consuming public. ${ }^{185}$ In addition, premium increases complicate access to the market for those with less ability to pay, raising the question of whether low-income individuals should receive government subsidies for purchasing coverage, and if so, how the means testing would occur. ${ }^{186}$ In short, it is difficult to

180. Id.; see also id. at 20-21 (discussing that the NFIP has social goals and objectives that insurers in the private market do not share).

181. Id. at 40-41.

182. Id. at 41 .

183. For a discussion of the pros and cons of the all-peril policy alternative, see GAO-08-7, supra note 162, at 36-41.

184. The controversial enactment of mandates in the Patient Protection and Affordable Care Act, Pub. L. No. 111-148, 124 Stat. 119 (2010), now repealed on a partyline vote in the December 2017 federal tax reform bill, Pub. L. No. 115-97, 131 Stat. 2054 (2017), shows the likely outcome of any serious effort to mandate flood insurance coverage in homeowners policies.

185. One concern is that where natural catastrophe risk is high, state regulators, many of whom are elected, would refuse to give private insurers authority to charge rates sufficient to cover the risk. See GAO-08-7, supra note 162, at 13.

186. Id. at 7, 33 . 
imagine a political consensus supporting this kind of major restructuring of the homeowners insurance market with respect to natural disaster risk.

\section{Ineffective Government Intervention to Support Private Insurance Markets}

Government-provided or government-subsidized insurance exists in a variety of areas where the private market is unable to supply insurance products deemed important to the public interest or is unable to do so at an affordable cost. This is most obvious in health care access, where insurance is the ticket to access to the health care system. Failures in the private insurance market were acknowledged over a half a century ago, and significant government involvement in health insurance markets resulted. ${ }^{187}$ Significant government intervention also occurred in the market for crop insurance, ${ }^{188}$ deposit insurance in the financial services industry, liability insurance for nuclear power generation, political risk insurance for some international business exports, crime insurance for certain properties in designated urban areas, terrorism insurance, and, of course, flood insurance. ${ }^{189}$

The details of the government role vary in each of these settings, but the common purpose of public intervention is to moderate premiums and maintain supply of the product. To accomplish these goals, the government must commit to make appropriations necessary to

187. Medicare and Medicaid, the two largest federal health insurance programs, together account for roughly $40 \%$ of all health care expenditures; the two programs' expenditures combined are more than all private health insurance expenditures. Ctrs. for Medicare \& Medicaid Servs., National Health Expenditures 2016 Highlights 2 (2016), available at https://www.cms.gov/Research-Statistics-Data-andSystems/Statistics-Trends-and-Reports/NationalHealthExpendData/Downloads/high lights.pdf.

188. A discussion of crop insurance is beyond the scope of this article, but crop insurance is an important part of the nation's flood preparedness strategy. For more discussion on this, see JERRY, supra note 76.

189. See JeRry \& Richmond, supra note 66, at 54. These examples are all federally based, but some state catastrophe programs exist as well, albeit in smaller scope. See, e.g., History of the California Earthquake Authority (CEA): It All Started With an Earthquake, CAL. EARTHQUAKE AuTH., https://www.earthquakeauthority.com/ About-CEA/CEA-History (last visited Sept. 11, 2018) [https://perma.cc/LV35-RZE5] (California created an earthquake fund in 1996 when private insurers significant stepped out); About Us: Who We Are, Citizens Prop. Ins. Corp., https://www.citi zensfla.com/who-we-are (last visited Sept. 11, 2018) [https://perma.cc/4PD8-EMJG] (Florida established Citizens Property Insurance Corporation in 2002 to provide state-backed insurance, but if a storm depletes its surplus, assessments on policyholders pay it back). Programs in Florida, Louisiana, Texas, and other states are funded through a combination of premium payments, post-event assessments, and bonds. In some of these programs, a deficit in the reserve is addressed through assessments on all, or some subset, of policies sold in the state for a period of years into the future. American Insurance Association, What Are "Residual Markets" for PropERTY INSURANCE? 1-2, available at http://www.aiadc.org/File\%20Library/Resources/ Industry\%20Resources/PROPERTY-National-_-Residual-Market-DescriptionsWhite-Paper-295953.pdf. 
fund compensation payments that exceed the program's reserves. An understandable desire to keep premiums low causes many of these programs to be under-reserved, which leads to these programs sometimes being unable to cover losses in a given year. The usual response is for Congress to appropriate additional funds to sustain the program and help it meet its obligations, which means losses are covered by general revenues and are spread across all taxpayers. In other settings, government assesses insurance companies for the deficits. This, in turn, causes insurers to seek approval-sometimes under threat of leaving the market entirely - to charge higher premiums across their entire product line, which spreads the loss across all policyholders. If insurers leave the market, this can create additional access issues and stress. ${ }^{190}$

A governmental presence in an insurance market does not mean that market forces vanish. When the government sells insurance in a market and keeps premiums low, insureds are attracted to the product, which will tend to crowd out products that private insurers might otherwise attempt to sell. This increases the percentage of the market covered by government insurance, which increases taxpayers' financial exposure. Moreover, when premiums are kept artificially low relative to the actual risk, policyholders do not receive signals about the cost of coverage or the costs of choices that increase risk (e.g., living in disaster-prone areas). In turn, policyholders will make choices that increase their exposures to risks, which increases losses.

The important government insurance program for hurricane risk is the NFIP because storm surge and inland flooding are the most dangerous and costly aspects of hurricanes. ${ }^{191}$ The NFIP has two primary purposes: first, to offer insurance to properties with significant flood

190. This is part of the narrative of the aftermath of the 2004 and 2005 hurricanes in Florida, where many large insurers left the market and some of the smaller ones became insolvent. See Nancy Dahlberg, Will Your Homeowner Insurance Protect You If the Big One Hits?, Miami Herald (Aug. 21, 2016, 4:00 PM), https://www.miamiherald.com/news/business/biz-monday/article96929132.html] [https://perma.cc/V6WCDQNV]. The lack of private market supply led to the formation of Citizens Insurance Company, a state-run property insurance company, which at one point was the largest insurance company in Florida. Leslie Scism, Why Florida Is Insured by Companies You've Never Heard of, WALl St. J. (Sept. 7, 2017), https://www.wsj.com/articles/whyflorida-is-largely-insured-by-companies-youve-never-heard-of-1504782003 [https:// perma.cc/7DTN-R2Z6]. In recent years, the state has tried to "depopulate" the number of policyholders holding Citizens policies. Id. See also Programs: Depopulation, Citizens Prop. Ins. CorP., https://www.citizensfla.com/depopulation (last visited Sept. 11, 2018) [https://perma.cc/5VLF-FPYJ]. Today, the Florida market, in contrast to the era pre-2004/2005, consists of many smaller insurers who rely on reinsurance to handle large losses. See Leslie Scism, Hurricane Michael to Test Florida's Unique Insurance Market, WALL ST. J. (Oct. 11, 2018, 5:30 AM), https://www.wsj.com/articles/ hurricane-michael-to-test-floridas-unique-insurance-market-1539250200 [https:// perma.cc/MK23-GU7M].

191. Diane P. Horn, Cong. Res. Serv., R45099, National Flood Insurance Program: Selected Issues and Legislation in the 115th Congress 1 (2018). 
risk; and, second, to reduce flood risk by implementing floodplain management standards. ${ }^{192}$ A long-term objective is to reduce federal expenditure on post-flood disaster assistance. ${ }^{193}$ When Congress first enacted the NFIP, the program's structure involved federal underwriting of coverage sold through private insurers. ${ }^{194}$ The number of policies sold, however, was unexpectedly low. In response, Congress revised the program so that the NFIP sold policies directly to the public. ${ }^{195}$ The take-up rates - which refers to the percentage of property owners in flood zones who purchase flood insurance-did not improve significantly. Thus, in 1983, Congress replaced direct government sales with a structure that continues today: a network of approved private insurance companies market the insurance, NFIP underwrites it, ${ }^{196}$ and a limited alternative track exists for acquiring insurance through the NFIP's direct servicing agent ("DSA") - a private contractor that represents FEMA in the sale, service, and claim adjustment on policies sold through this alternative track. ${ }^{197}$ The NFIP is more, however, than a publicly-funded insurance program; the program's other features involve identifying and mapping flood risk, encouraging floodplain risk reduction, communicating flood risk information to the public, and many other non-insurance activities. ${ }^{198}$

The evolution of the NFIP and how it functions are beyond the scope of this discussion, but the consistent theme is that the penetration of flood insurance in flood-prone areas, especially those confronting hurricane risk, is remarkably low. ${ }^{199}$ For those in flood plains and coastal areas, the exact take-up rate is unknown, but available data suggests it is about $50 \%$ overall. ${ }^{200}$ Outside designated flood zones, the take-up rate for residential properties is closer to $20 \%$, a

192. Id.

193. $I d$.

194. Id. at 22,32 .

195. $I d$.

196. Professor Scales summarizes the program as follows: "This arrangement is known as the Write-Your-Own ("WYO") program, though that title is misleading. The insurance contract is written by the NFIP and published in the Federal Register. No deviations are permitted, and it is not governed by the law of insurance contracts generally. Insurance companies retain $30 \%$ of premiums as a commission and receive compensation for additional loss-adjustment expenses. These insurers are responsible for enrolling policyholders, collecting premiums, and administering claims. In a number of respects-not all intended by Congress - they resemble the administrators of ERISA plans: private insurers who wear one hat while fulfilling their own policy obligations and wear another when they function as agents of the ERISA fiduciary. Similarly, WYO insurers have been described as "fiscal agents" of the federal government, a denomination that permeates their legal relationship to policyholders." See Scales, supra note 151 , at $14-17$.

197. Carolyn Kousky, Financing Flood Losses: A Discussion of the National Flood Insurance Program, 21 Risk Mgmt. \& Ins. Rev. 11, 15 (2018).

198. Id. at 12; HoRn, supra note 191, at 25.

199. For a discussion of current issues affecting the NFIP and a summary of research on the economics of the program, see Kousky, supra note 197, at 2.

200. Id. 
figure that closely tracks the number of flooded properties with flood insurance coverage after Hurricane Harvey and Superstorm Sandy. ${ }^{201}$ Moreover, NFIP policies are distributed unevenly around the country; five states (Florida, Texas, Louisiana, California, and New Jersey) account for two-thirds of all U.S. policies, and two of these states (Florida, 37\%; and Texas, $11 \%$ ) account for almost half of all the policies. $^{202}$ Because of low take-up rates and increasing disaster payouts, the program is deeply in debt, despite the fact that coverage under the program is thinner than many realize. ${ }^{203}$ For example, residential property coverage is capped at $\$ 250,000$, does not cover living costs if displaced from a damaged property, and does not provide coverage for personal belongings. ${ }^{204}$

Developing a more stable flood insurance program has proved elusive. To encourage greater participation in the program, premiums need to be kept low; but maintaining lower premiums is at odds with maintaining the fiscal soundness of the program. Conversely, when flood insurance premiums are priced at actuarially accurate levels to promote fiscal soundness, the policies are too expensive for many. The NFIP provides subsidies to policyholders to assist them with paying their premiums, which is generally a noncontroversial way for the government to support insurance markets, but the introduction of subsidies complicates efforts to maintain fiscal soundness. ${ }^{205}$

The program is also hampered by anomalies that defeat actuarial soundness and exacerbate fiscal imbalance. Chief among these anomalies is that the program encourages reconstruction of damaged homes and businesses in areas subject to recurrent flooding. According to The Pew Charitable Trusts, structures rebuilt multiple times after flooding constitute only $1 \%$ of NFIP policies, but they account for $25-30 \%$ of claims. ${ }^{206}$ Compelling evidence exists that shows that risks

201. See supra notes 160-61.

202. Kousky, supra note 197, at 20.

203. Mary Williams Walsh, A Broke, and Broken, Flood Insurance Program, N.Y. Times (Nov. 4, 2017), https://www.nytimes.com/2017/11/04/business/a-broke-and-bro ken-flood-insurance-program.html [https://perma.cc/MGB9-3JLR]. The program has been in debt since Hurricane Katrina. Id.

204. See FEMA, National Flood Insurance Program: Summary of CoverAGE 1-3 (2012), available at https://www.fema.gov/media-library-data/20130726-162020490-4648/f_679_summaryofcoverage_11_2012.pdf. These limitations are often cited as reasons to encourage private insurers to enter the flood insurance market.

205. Carolyn Kousky \& Leonard Shabman, Pricing Flood Insurance: How and Why the NFIP Differs from a Private Insurance Company 1 (2014), available at http://www.rff.org/files/sharepoint/WorkImages/Download/RFF-DP-1437.pdf.

206. Repeatedly Flooded Properties Cost Billions, PEW (Oct. 6, 2016), http://www. pewtrusts.org/en/research-and-analysis/data-visualizations/2016/repeatedly-floodedproperties-cost-billions [https://perma.cc/ZQ27-UBUA]. These so-called "repetitive loss properties" cost approximately half of the NFIP's debt as it stood in 2016. Approximately $10 \%$ of these properties have received payments in excess of their values, and the number of such properties is increasing at the rate of about 5,000 a year. Id. 
and premiums are mismatched in the program. ${ }^{207}$ After Hurricane Katrina caused NFIP deficits to soar, analysis of policies in force revealed that roughly $20 \%$ of NFIP policyholders had been paying rates below what NFIP defines as a full-risk premium. ${ }^{208}$ But a recent study of North Carolina properties found that NFIP premiums are "significantly higher than risk-based premiums for more than $90[\%]$ of the homes in each of the counties and more than 87.4[\%] of the samples in each of the four analyses [in the study]." ${ }^{209}$ Flood-zone maps are out of date and inaccurate in many locations, which causes premium and risk mismatches. ${ }^{210}$ Further, because the program sets premiums based on average historical losses within a flood zone rather than each individual property's flood risk, high-value homes are underpriced relative to low-value homes. Because property values correlate with owners' wealth, this mismatch results in an anomalous cross-subsidy of wealthier insureds by poorer insureds. ${ }^{211}$

In 2012, Congress attempted to address these problems by enacting a far-reaching reform of the NFIP. The revisions priced flood insurance closer to actual risk, phased out subsidies, eliminated repetitive loss properties from the programs, and provided funds to update flood maps. ${ }^{212}$ But public resistance, especially from coastal property own-

207. See Ctr. for Ins. Policy \& Res., Flood Risk and Insurance 3 (2017), available at https://www.naic.org/documents/cipr_study_1704_flood_risk.pdf; Vivien Lee \& David Wessel, The Hutchins Center Explains: National Flood Insurance Program, BRoOKINGS, (Oct. 10, 2017), https://www.brookings.edu/blog/up-front/2017/10/ 10/the-hutchins-center-explains-national-flood-insurance-program/ [https://perma.cc/ $\mathrm{KH} 5 \mathrm{~V}-\mathrm{PJCL}]$ (" $[\mathrm{P}]$ remiums are too low, given the risks that the program takes. This mismatch reflects political resistance against premiums that actually reflect flooding risks, flawed mapping methods that don't accurately assess flood risks, lax enforcement of program rules, and the cycle of rebuilding damaged properties with NFIP payouts (often without risk mitigation such as relocations, removals or building elevations), only to be flooded again. Further, obsolete FEMA flood-risk maps tend to distort premiums, hinder property relocation to safer areas, and obscure the risk of flood-prone areas from consumers. NFIP 'grandfathering' practices allow property owners to follow rules based on older versions of FEMA flood maps. For example, buildings constructed in compliance with previous flood ratings are not required to update their structural requirements, even if new classifications indicate greater flooding risk.").

208. Kousky \& Shabman, supra note 205, at 1. A 2011 report by the Property Casualty Insurers Association of America estimated that premiums households pay are, on average, about half of what would be charged in the private market, and in high-risk areas, premiums are about one-third. Lee \& Wessel, supra note 207.

209. Howard Kunreuther et al., Structure Specific Flood Risk Based Insurance, 4 J. Extreme Events 3, 11 (2017).

210. See Michael Keller et al., Outdated and Unreliable: FEMA's Faulty Flood Maps Put Homeowners at Risk, BloOMBerg (Oct. 6, 2017), https://www.bloom berg.com/graphics/2017-fema-faulty-flood-maps/ [https://perma.cc/6URA-2JZ4].

211. See Ike Brannon \& Ari Blask, The Government's Hidden Housing Subsidy for the Rich, Politico (Aug. 8, 2017, 5:38 AM), https://www.politico.com/agenda/story/ 2017/08/08/hidden-subsidy-rich-flood-insurance-000495 [https://perma.cc/F5AJ9RBH].

212. Biggert-Waters Flood Insurance Reform Act of 2012, Pub. L. No. 112-141, 126 Stat. 916. 
ers who experienced steep increases in premiums as the risk-adjustments occurred, led to the repeal of the 2012 reforms fourteen months later. ${ }^{213}$ The resistance was understandable; those policyholders who benefited from subsidized insurance after receiving encouragement to move into and build in high-risk areas were not interested in reforms that better matched premiums with risk. At the time of this Article, how this will finally resolve, if it does, is uncertain. ${ }^{214}$

Despite deficiencies in the federal intervention in flood insurance markets, governmental interventions in insurance markets are not always flawed. Although imperfect, state regulation of insurance companies for solvency through reserve and capital requirements has generally been effective, as have state regulatory efforts with respect to licensing, anti-discrimination, and unfair trade practices. ${ }^{215}$ Federal interventions in other areas have also successfully achieved their goals. ${ }^{216}$ Although the NFIP has not functioned so well, at some point the NFIP will be repaired and modified with a mix of reforms selected from some of the following items: (1) requiring all owners of property with mortgages to purchase flood insurance, instead of only owners of properties located in flood-prone areas, or, alternatively, requiring all owners of property in designated flood zones to purchase flood insurance without regard to the properties' encumbrances; (2) increasing

213. See Logan Strother, Five Reasons That Flood Insurance Will Fail Without Reform, Post and Courier (Sept. 17, 2017), https://www.postandcourier.com/opinion/ commentary/five-reasons-that-flood-insurance-will-fail-without-reform/article_0f14ed 4e-99a0-11e7-a601-ffda4152bcc5.html [https://perma.cc/586R-DJY3].

214. As the NFIP reauthorization deadline approached in 2018, Congress was unable to forge a consensus set of reforms to guide the program moving forward. On July 31, 2018, Congress passed, and President Trump signed, a short-term extension of the NFIP, just hours before the program was set to expire on August 1, until November 30,2018 , but no progress has been made in addressing needed long-term reforms in the program exacerbated by the losses in the 2018 hurricane season.

215. See JERry \& Richmond, supra note 66, at 86-95.

216. The federal deposit insurance system has helped maintain confidence in the national banking system and played a major role in averting worse conditions that easily could have unfolded during the recession that began in 2008. See Federal DePOSIT InSURANCE CORPORATION, https://www.fdic.gov/ [https://perma.cc/7FF8KG9A]; see FDIC, CRisis AND Response: An FDIC History, 2008-2013 (2017), available at https://www.fdic.gov/bank/historical/crisis/crisis-complete.pdf. The federal backstop in the Terrorism Risk Insurance Act, first enacted in 2002, has been effective in stabilizing insurance markets that were thrown into chaos by the September 11 attacks. For more background, see Terrorism Risk Insurance Program, U.S. DeP'T TREASURY, https://www.treasury.gov/resource-center/fin-mkts/Pages/program.aspx [https://perma.cc/6ZQT-CCDL]. The core problem faced by the nation's elderly population in the late 1950s and early 1960s was that private insurers would not sell them insurance or would do so under conditions of very limited coverage terms, or very high, often unaffordable, premiums. Although controversial when enacted and still not immune from critique, any fair assessment of Medicare must conclude that it solved the problem of access to health care for almost all of the nation's elderly, and fifty years later, it is hard to imagine that the nation's political leaders would have support for returning the country to pre-1965 approaches to insuring the health care needs of the elderly. 
the accuracy and granularity of NFIP rates through new technologies and big data analytics that measure flood risk and adjust premiums to risk; (3) eliminating the ability of high-risk properties to make recurrent claims on the NFIP by allowing only one total loss claim per insured location; because this measurement would run with the land and apply to future owners, some owners, upon a total loss, would opt to relocate or at least not rebuild; also, prospective buyers would be deterred from purchasing a property they could not insure; (4) as premiums rise for some properties due to risk adjustments, providing means-based subsidies to low-income insureds to maintain access to coverage; (5) expanding the circumstances under which the program might purchase flood-damaged property in lieu of paying proceeds to the owner, and converting the property to public lands; (6) providing premium reduction incentives to insureds who invest in loss-prevention and mitigation strategies; (7) assessing higher premiums for second homes, vacation homes, and investment properties; and (8) encouraging an increased role for private companies in insuring flood risk, accompanied by investments in NFIP prevention and mitigation efforts to offset loss of policy fees that would accompany an increased private role. ${ }^{217}$ NFIP deficit forgiveness will likely also accompany this mix of reforms.

\section{Incomplete and Mismatched Disaster Relief}

Using government powers to assist disaster victims has a long history in the U.S., but the expectation that this is a core responsibility of government did not emerge until the last half of the 20th century. The first known federal relief effort occurred in 1803 when Congress suspended the obligation of Portsmouth, New Hampshire merchants to make bond and tariff payments to the federal government in the aftermath of a devastating fire that destroyed large areas of the seaport. ${ }^{218}$ On 128 occasions between 1803 and 1947, Congress enacted legislation to provide ad hoc relief-usually in the nature of medical supplies, food, and clothing, or funds to purchase these items-to victims of various natural disasters. ${ }^{219}$ Yet the idea that the federal government had primary responsibility for assisting natural disaster victims was not widely accepted. Thus, the federal government deferred to local government agencies to provide direct relief in the aftermath of two massive disasters in the early 20th century-the 1900 Galveston Hurricane and the 1906 San Francisco earthquake. The federal gov-

217. Discussions of how to reform the NFIP are legion. For a useful summary, see U.S. Gov't Accountability Off., Flood Insurance: Comprehensive Reform Could Improve Solvency And Enhance Resilience (2017), available at https:// www.gao.gov/assets/690/684354.pdf.

218. FEMA, The Federal Emergency Management Agency 3 (2010), available at https://www.fema.gov/media-library-data/20130726-1823-25045-8164/pub_1_fi nal.pdf (visited June 18, 2018).

219. Moss, supra note 81 , at 312 . 
ernment's limited reaction to these two disasters was, however, controversial, and this led to a national discussion about the proper role of the federal government in providing relief after major disasters. ${ }^{220}$ Thus, when the Great Mississippi Flood of 1927 devastated cities and towns throughout the central U.S., President Coolidge directed Commerce Secretary Herbert Hoover to coordinate a federal disaster relief response. ${ }^{221}$ The 1936 Flood Control Act encouraged the evolving acquiescence that the federal government had a role in disaster relief. ${ }^{222}$ Since 1824, the U.S. Army Corps of Engineers had built and managed canals and levees to promote domestic maritime commerce, ${ }^{223}$ but the 1936 statute for the first time declared flood control as a federal activity and authorized hundreds of federal flood control projects under the direction of the Corps of Engineers. ${ }^{224}$

By passing the Disaster Relief Act in 1950, Congress fully embraced the proposition that disaster relief is a federal responsibility. ${ }^{225}$ This statute created the nation's first permanent federal disaster relief fund and authorized the federal government to provide relief in the aftermath of "flood, drought, fire, hurricane, earthquake, storm, or other catastrophe in any part of the United States, which in the determination of the President" is sufficiently severe to justify federal interven-

220. Id.

221. Id.

222. 33 U.S.C. $\S 701 \mathrm{a}$ (2012) (setting out as the declaration of policy of the 1936 Act that, in part, "it is the sense of Congress that flood control on navigable waters or their tributaries is a proper activity of the Federal Government in cooperation with States ... that investigations and improvements of rivers and other waterways, including watersheds thereof, for flood-control purposes are in the interest of the general welfare; that the Federal Government should improve or participate in the improvement of navigable waters or their tributaries . . . for flood-control purposes if the benefits to whomsoever they may accrue are in excess of the estimated costs, and if the lives and social security of people are otherwise adversely affected").

223. A Brief History: Improving Transportation, U.S. Army Corp Eng'Rs, https:// www.usace.army.mil/About/History/Brief-History-of-the-Corps/Improving-Transportation/ (last visited Sept. 10, 2018) [https://perma.cc/YAD5-DR4H]. The U.S. Army Corp of Engineers was established in 1802, essentially as a successor to the army engineers who belonged to the Continental Army and assisted in the Revolutionary War. A Brief History: The Beginnings to 1815, U.S. Army Corp EnG'Rs, https://www.usace .army.mil/About/History/Brief-History-of-the-Corps/Beginnings/ (last visited Sept. 10, 2018) [https://perma.cc/VWF5-UYYR]. A pair of statutes enacted by Congress in 1824 authorized the use of Army engineers to survey road and canal routes, and to improve the navigation of the Ohio and Mississippi Rivers. A Brief History: Improving Transportation, supra.

224. A Brief History: Multipurpose Waterway Development, U.S. Army Corp ENG'Rs, https://www.usace.army.mil/About/History/Brief-History-of-the-Corps/Intro duction/ (last visited Sept. 10, 2018) [https://perma.cc/4826-N9E5].

225. Federal Disaster Relief Act of 1950, Pub. L. No. 81-875, § 1, 64 Stat. 1109, 1109 (1950) ("[I]t is the intent of Congress to provide an orderly and continuing means of assistance by the Federal Government to States and local governments in carrying out their responsibilities to alleviate suffering and damage resulting from major disasters, to repair essential public facilities in major disasters, and to foster the development of such State and local organizations and plans to cope to with major disasters as may be necessary."). 
tion to provide relief. ${ }^{226}$ As a result, significant disaster experiences in the 1960s had a visible federal presence in post-disaster relief efforts. ${ }^{227}$ Congress created the NFIP in 1968, expanded the 1950 federal disaster relief program through the Disaster Relief Act of 1970, and established the Federal Disaster Assistance Administration, FEMA's predecessor, in 1974.228

By the 1970s, the federal disaster relief framework had become a patchwork of congressional interventions and reforms, with federal disaster policy and relief efforts fragmented across approximately 100 different federal agencies. ${ }^{229}$ In response, President Carter signed an executive order in 1979 that combined the disaster relief and civil defense responsibilities of several separate federal agencies into the newly created FEMA. ${ }^{230}$ Subsequent congressional actions added earthquake preparedness and mitigation, emergency food and shelter

226. Id. $\S \S 2(\mathrm{a}), 3,8$.

227. The Alaska Earthquake in 1964, Hurricane Betsy in 1965, and Hurricane Camille in 1969 were the major natural disasters of that era. Hurricane Betsy was the largest hurricane disaster to ever occur at the time; it was the first hurricane to cause more than $\$ 1$ billion in damage. See Scott, supra note 91. In current dollars, the damage caused by Betsy would be $\$ 9.6$ billion, but given the increased development in the areas where Betsy made landfall, a similar hurricane would cause approximately $\$ 57$ billion in insured losses if it were to occur today. See AIR Worldwide, Top 10 Historical Hurricanes: What Would They Cost Today?, VERIsk (Oct. 12, 2017), https://www. verisk.com/insurance/visualize/top-10-historical-hurricanes-what-would-they-cost-to day/ [https://perma.cc/AZ5A-MWWZ]. After Betsy, Congress ordered the Army Corps of Engineers to build levees around New Orleans. Bob Marshall, New Orleans' Flood Protection System: Stronger Than Ever, Weaker Than It Was Supposed to Be, The Lens (May 15, 2014, 6:00 AM), https://thelensnola.org/2014/05/15/new-orleansflood-protection-system-stronger-than-ever-weaker-than-it-was-supposed-to-be/

[https://perma.cc/NQ4U-G7RA] (reporting on the history of New Orleans's walls and levees which began with the Lake Pontchartrain and Vicinity Hurricane Protection Project). The notorious failure of these levees to protect major sectors of New Orleans in the wake of Hurricane Katrina prompted much controversy post-Katrina. See, e.g., Ivor LI. van Heerden, The Failure of the New Orleans Levee System Following Hurricane Katrina and the Pathway Forward, 67 Pub. Admin. Rev. 24, 35 (2007) ("The infrastructure failures observed in the Greater New Orleans area ... resulted in the loss of life and major property damage and destruction. These failures were manmade and could have been prevented. A combination of engineering errors and political decisions resulted in a hurricane protection system of lesser quality than was promised to the citizens of Louisiana ....").

228. U.S. Dep't Housing \& Urban Dev., Fed. Disaster Assistance Admin. Program Guide 1-2 (1976) ("The President's declaration of a 'major disaster' or 'emergency' authorizes Federal Assistance under the Disaster Relief Act of 1974 and triggers other Federal disaster relief programs. The federal response is coordinated by the Federal Disaster Assistance Administration . . . of the Department of Housing and Urban Development. By executive order 11795, the President delegated the primary responsibility for administering the Act to the Secretary of Housing and Urban Development.").

229. See Garrett M. Graff, The Secret History of FEMA, WIREd (Sept. 3, 2017, 7:00 AM), https://www.wired.com/story/the-secret-history-of-fema/ [https://perma.cc/63P4LNKQ].

230. Exec. Order No. 12148, 44 Fed. Reg. 43239 (July 20, 1979). 
assistance, enhanced disaster relief, and dam safety to the FEMA mission. ${ }^{231}$

In 1988, Congress passed the Stafford Disaster Relief and Emergency Assistance Act, which encouraged state and local governments to engage in enhanced preparedness and public assistance programs, direct assistance to households, hazard-mitigation efforts to reduce the effects of disasters, and land use and construction regulations. This statute also created the presidential disaster-declaration machinery, which makes state and local governments the default first responders to natural disasters, with a presidential disaster-area declaration amounting to a determination that a disaster is too severe for state and local governments, with the aid of private agencies, to manage relief efforts without federal assistance. ${ }^{232}$

In the aftermath of the 9/11 terrorist attacks, Congress combined twenty-two federal agencies in 2002, including FEMA, into the presidential-cabinet-level Department of Homeland Security. ${ }^{233}$ The effectiveness of this reorganization was much debated at the time, ${ }^{234}$ and at least two FEMA directors warned that the complexities and intraagency competition for resources had substantially eroded FEMA's ability to respond to a natural disaster. ${ }^{235}$ Hurricane Katrina validated

231. Earthquake Hazards Reduction Act of 1977, Pub. L. No. 95-124, 91 Stat. 1098 (earthquake preparedness and mitigation); Stewart B. McKinney Homeless Assistance Act, Pub. L. No. 100-77, 101 Stat. 482 (1987) (emergency food and shelter assistance); Disaster Relief Act of 1974, Pub. L. No. 93-288, 88 Stat. 143 (enhanced disaster relief); Water Resources Development Act of 1996, Pub. L. No. 104-303, 110 Stat. 3658 (establishing a national dam safety program).

232. The Robert T. Stafford Disaster Relief and Emergency Assistance, supra note 24. Under the Stafford Act framework, a presidential disaster declaration may authorize either or both of two programs: Public Assistance, which provides aid to local governments, and Individual Assistance, which helps households. SHAwn ReEse, Cong. Res. Serv., R45085, FEMA Individual Assistance Programs: In Brief 1 (2018). A third program, Mitigation Assistance, is included in all disaster declarations. Id.

233. Homeland Security Act of 2002, Pub. L. No. 107-296, 116 Stat. 2135.

234. See, e.g., Jonathan Thessin, Department of Homeland Security, 40 Harv. J. ON Legis. 513, 525-31 (2003); Pete Brush, The Homeland Security Debate, CBS (June 11, 2002), https://www.cbsnews.com/news/the-homeland-security-debate/ [https:// perma.cc/9C7P-C66A]; Bush Signs Homeland Security Bill, CNN (Nov. 26, 2002, 1:10 AM), http://www.cnn.com/2002/ALLPOLITICS/11/25/homeland.security/ [https:// perma.cc/5LT9-2X9B].

235. In 2004, James Witt, who served as Director of FEMA from 1993 to 2001, expressed concern that the nation's ability "to prepare for and respond to disasters" had been "sharply eroded." The Homeland Security Department's Plan to Consolidate and Co-locate Regional and Field Offices: Improving Communication and Coordination Before the Subcomm. on Energy Policy, Nat. Res. \& Regulatory Affairs, 108th Cong. (2004) (statement of James Lee Witt, Former Director of the Federal Emergency Management Agency). In 2003, then-FEMA Director Michael Brown complained in a memo that the "capacity" of FEMA had "disintegrated" as a result of the reorganization. Michael Grunwald \& Susan B. Glasser, Brown's Turf Wars Sapped FEMA's Strength, WASH. Post (Dec. 23, 2005), https://www.washingtonpost.com/ archive/politics/2005/12/23/browns-turf-wars-sapped-femas-strength/323fd421-78f3-44 ce-a667-9c60c5473d86/?utm_term=.352216453cfc [https://perma.cc/J84M-JTAR]. 
these predictions when it made landfall in 2005; the federal response to Katrina was widely criticized for its delay, disorganization, and inadequacy, and FEMA took the brunt of much of this criticism. ${ }^{236}$ In direct response, Congress passed the Post-Katrina Emergency Management Reform Act in 2006, ${ }^{237}$ which restated FEMA's core missions as "preparedness, protection, response, recovery, and mitigation." 238 This broadly defined set of purposes explicitly acknowledged the federal government's role in all phases of a disaster, including pre-disaster planning and preparation, civil protection as a disaster unfolds, and post-disaster relief. ${ }^{239}$

Few argue that disaster relief is unimportant when catastrophe strikes, but a problem arises when the expectation of disaster relief encourages underinvestment in preparation, which leads to a greater need for disaster relief in the aftermath of disasters. Spending ex ante for loss prevention, mitigation, and insurance is illogical if ex post assistance is forthcoming. ${ }^{240}$ This moral hazard problem is what economist James Buchanan described as the Samaritan's dilemma; ${ }^{241}$ if individuals and firms expect disaster relief ex post, they will underinvest in prevention, mitigation, and insurance. ${ }^{242}$ Kousky, MichelKerian, and Raschky found in their research that "federal post-disaster grants provided to households for uninsured losses have a negative impact on average insurance coverage across all measures of [Individual Assistance], although significance levels vary."243

Moreover, even granting that ex post disaster spending is suboptimal when compared to equivalent investments in pre-loss prevention and mitigation, it is impossible to imagine a congressional majority resisting calls to increase relief spending whenever disaster strikes. Elected officials assume that they will pay dearly in the political process if they are perceived to oppose post-disaster spending. ${ }^{244}$ Media

236. See Patrick Marshall, Disaster Readiness: Is FEMA Prepared for Weather Catastrophes?, CQ RESEARCHER (Jan. 12, 2018), http://library.cqpress.com/cqresearcher/ document.php?id=CQresrre2018011203 [https://perma.cc/6R6U-J4TA] (discussing how "FEMA's public image hit a new low" during and after the Katrina response).

237. Post-Katrina Emergency Management Reform Act of 2006, Pub. L. 109-295, 120 Stat. 1394.

238. Id. $\$ 503$.

239. A comprehensive summary of how disaster relief is delivered through federal mechanisms is beyond the scope of this article, but FEMA is not the only agency through which disaster relief is provided. See GAO-08-7, supra note 162, at 15-17.

240. See Michel-KerJan \& Volkman-Wise, supra note 146, at 4.

241. See James Buchanan, The Samaritan's Dilemma, in Altruism, Morality, AND ECONOMic Theory 71-85 (Edmund S. Phelps ed., 1975).

242. See Carolyn Kousky et al., Does Federal Disaster Assistance Crowd out Flood Insurance?, 87 J. EnvTl. ECON. \& MGMT. 150, 151 (2018). The term "charity hazard" is also used to refer to the effect of private philanthropy crowding out the purchase of insurance. $I d$. at 151.

243. Id. at 162.

244. See id. 
attention on the suffering of disaster victims is extensive. ${ }^{245}$ When this is coupled with the public's deeply held expectation that the government will provide ex post relief, ${ }^{246}$ media coverage helps make the consequences of perceived unresponsiveness to disasters by public officials potentially severe. ${ }^{247}$

In addition, the budgeting process for natural disasters, as a practical matter, forecloses efforts to constrain spending, should Congress desire constraint. FEMA bases its budget requests on past major disasters, but this approach has not anticipated extraordinary loss years and has usually failed to reserve sufficient funds to cover any given year's disaster costs. ${ }^{248}$ Thus, a pattern has developed where Congress appropriates emergency funds in the aftermath of a natural disaster to supplement the exhausted FEMA budget. ${ }^{249}$ This ad hoc, case-by-case approach is not a coherent strategy; in fact, the pattern of appropriations suggests that political considerations, rather than an objective measure of need, are the overriding factors in how much relief is provided in response to particular catastrophes. ${ }^{250}$

245. J. Brian Houston et al., Disaster News: Framing and Frame Changing in Coverage of Major U.S. Natural Disasters, 2000-2010, 89 Journalism \& MAss Comm. Q. 606, 613 (2012) ("Disaster characteristics that are likely to drive news coverage include the number of people killed by the disaster, number of people injured, number of people affected in other ways, and amount of destruction and damage.").

246. This increased expectation is evident in the increased number of presidential major disaster declarations in recent years. See Disaster Declarations by Year, FEMA, https://www.fema.gov/disasters/year?field_dv2_declaration_type_value=dr\&=apply

(last visited Sept. 11, 2018) [https://perma.cc/5JAC-BVZ7]. There were 186 declarations issued in the 1960s and 560 in the 2000s. Id. From 2010 to 2018, 522 have been issued. $I d$.

247. See, e.g., Douglas Brinkley, The Flood That Sank George W. Bush, VAnity FAIR (Aug. 26, 2015), https://www.vanityfair.com/news/2015/08/hurricane-katrinageorge-w-bush-new-orleans (last visited July 10, 2018) [https://perma.cc/MC88M5XQ]; Two-in-Three Critical of Bush's Relief Efforts, PEW REs. CTr. (Sept. 8, 2005), http://www.people-press.org/2005/09/08/two-in-three-critical-of-bushs-relief-efforts/ [https://perma.cc/4MML-3XYY]. The political ramifications of the governmental response to the three 2017 hurricanes are still uncertain. The weight of opinion is that the Trump administration's response to the effects of Hurricane Maria in Puerto Rico was deficient. See Robinson Meyer, What's Happening With the Relief Effort in Puerto Rico?, The Atlantic (Oct. 4, 2017), https://www.theatlantic.com/science/ archive/2017/10/what-happened-in-puerto-rico-a-timeline-of-hurricane-maria/541956/ [https://perma.cc/85ZC-XJFN]. But differences existed in the administration's responses to Hurricanes Harvey, Irma, and Maria, in that quicker and more robust responses occurred in response to the losses in Texas and Florida. See Ron Nixon \& Matt Stevens, Harvey, Irma, Maria: Trump Administration's Response Compared, N.Y. Times (Sept. 27, 2017), https://www.nytimes.com/2017/09/27/us/politics/trumppuerto-rico-aid.html [https://perma.cc/JWE9-S64A]; Danny Vinik, How Trump Favored Texas Over Puerto Rico, Politico (Mar. 27, 2018), https://www.politico.com/ story/2018/03/27/donald-trump-fema-hurricane-maria-response-480557 [https:// perma.cc/SP4B-JGCB].

248. Marshall, supra note 236.

249. Id.

250. See Nicole Einbinder, How the Response to Hurricane Maria Compared to Harvey and Irma, FronTLine (May 1, 2018), https://www.pbs.org/wgbh/frontline/arti cle/how-the-response-to-hurricane-maria-compared-to-harvey-and-irma/ [https:// 
In response to the Samaritan's dilemma, the government could require a commitment to purchase flood insurance on a going-forward basis as a condition of receiving disaster relief currently. This requirement would improve take-up rates, albeit with impact largely limited to areas already suffering hurricane damage. Interestingly, Kousky et al., also found that Small Business Administration disaster-relief loans "have almost no impact on insurance demand." ${ }^{251}$ This latter finding is not surprising, as recipients disfavor loans relative to grants simply because loans must be repaid and, unlike grants, do not provide relief from failures to purchase insurance. Although the study could not test whether consumers fail to purchase insurance when the receipt of disaster relief is not conditioned on the purchase of insurance, they reasoned that "it does seem that [such a requirement] is effective in preventing decreases in take-up rates after a disaster." ${ }^{252}$ The Kousky, et al. results suggest that increasing loans and limiting the growth in grants would be more likely to incentivize the purchase of insurance. Any plan to increase the flood insurance take-up rate must contend with the problem that many lower-income residents lack the financial capacity to meet an insurance-purchase or prevention-mitigation investment condition. Thus, some kind of subsidy system will need to be a part of this kind of reform. In addition, this system would require an enforcement mechanism for disaster relief recipients who fail to adhere to their insurance purchase commitments.

Another option for disaster relief reform, and one which FEMA has proposed, would require states to spend a designated amount each year on disaster preparedness to be eligible for federal financial assistance after major disasters. ${ }^{253}$ Not surprisingly, state and local officials, who tend to resist any mandate on increased state expenditures coming from the federal government, have strongly resisted this disaster-deductibles proposal. ${ }^{254}$ Yet these officials will be among the first to request massive infusions of federal disaster relief assistance whenever a catastrophe strikes. A deductible structure could be an effective incentive for $e x$ ante prevention and mitigation efforts. The structure

perma.cc/4RNC-5ZNR] (comparing the response by FEMA to Harvey (Texas), Irma (Florida), and Maria (Puerto Rico), and finding the immediate response to Maria far behind the other two in terms of supplies delivered and personnel deployed). See also Maya Lau, California Lawmakers Upset That Wildfire Money Is Left out of White House's Disaster Aid Request, L.A. Times (Nov. 19, 2017, 4:10 PM), https://www.la times.com/local/lanow/la-me-california-wildfire-funds-20171119-story.html [https:// perma.cc/TE5D-QLSR] (noting California lawmakers' sentiment "that it was 'mindboggling' the Trump administration did not include any funds for California [wildfire recovery] in its latest request, most of which will go to hurricane relief in Texas and Florida.").

251. Kousky et al., supra note 242, at 162.

252. Id.

253. See FEMA, Establishing a Deductible for FEMA's Public Assistance Program, 82 Fed. Reg. 4064 (Jan. 12, 2017) (to be codified at 44 C.F.R. pt. 206).

254. See Marshall, supra note 236. 
should take into account the challenges facing small states with small budgets; thus, the deductible could be tied to population size, the state's share of GDP, or some other metric that accounts for a particular state's ability to pay.

Overall, the prospects for reforming the current approach to disaster relief are not encouraging. Although public perceptions of natural disaster risk may be susceptible to shifts in light of the recent experiences of the 2017 season, Professors Healy and Malhotra found that voters do not incentivize politicians to support pre-disaster planning and investment in loss reduction and mitigation but do expect postloss government disaster relief and will punish politicians who fail to provide it. ${ }^{255}$ This suggests that the mismatch between investment and disaster relief is ultimately grounded in widespread public misapprehension of the costs of failing to invest in national preparedness, which helps explain why the government has tilted its priorities decidedly in favor of disaster relief. Healy and Malhotra put it succinctly: "[a]n ounce of prevention would be far more efficient than a pound of cure, but voters seem interested only in the cure." 256 On the other hand, although government underinvestment in disaster preparation is endemic, it is noteworthy that government does not underinvest in terrorism prevention and airline security, as the post-9/11 responses vividly illustrate. ${ }^{257}$ This discrepancy is predicted by the heuristic that highly observable events with horrific consequences are perceived as carrying more risk than abstract events that happen less frequently. The losses of the 2017 hurricane season might have more salience with the public than previous hurricane events. A fair prediction, however, is that this will not be the case. In 2006, Congress quickly acted with a package of disaster-relief statutory reforms after Katrina, but interest in hurricane preparedness faded within a few years, suggesting that hurricane disasters only have a temporary impact on public attention. $^{258}$

\section{The Natural Disaster Risk Management Future}

The lack of a comprehensive, effective government strategy for natural disaster risk management, and the history of the uncompleted efforts to craft one, should be sufficient to demonstrate that creating such a policy is as much a political problem as it is a risk management and insurance problem. Except for the consequences of a war fought partially on American soil, a successful terrorist attack that renders parts of the U.S. uninhabitable for years or decades, or a pandemic, no threat to the homeland exists that surpasses natural disaster risk. Thus, any national preparedness strategy designed to manage such an

255. See Healy \& Malhortra, supra note 147, at 388.

256. Id. at 402 .

257. Id.

258. See id. at 403. 
eventuality must involve a consensus forged in a national conversation that includes the executive and legislative branches of the federal government.

Although understanding risk management and insurance as a niche within the larger political system is not the way insurance discussions are usually framed, the insight that politics plays a role in natural disaster risk management is not especially remarkable. It has long been understood that risk management and insurance mechanisms exist and operate within the larger political system where values and assets are allocated. ${ }^{259}$ Government actors, private individuals, firms, and insurance companies constantly make choices about whether to invest in (or reward) mitigation or prevention, what kinds and scope of coverages to make available at what prices, which individuals or firms to allow to enter risk distribution pools, or which underwriting classifications to use or permit to be used. The sum of these choices allocates and distributes resources and assets in society. How the resulting gains, losses, benefits, and burdens are allocated will be a part of, and will ultimately align with, the allocation of values, assets, and resources in the larger political system.

Risk management in any context rarely involves simple questions and obvious choices, but when a risk implicates national security and affects tens of millions of people, even imagining solutions that do not require a national political conversation is very difficult. The most basic lesson of the risk management-recovery matrix is that the calculus for creating a national preparedness policy for natural disasters is extraordinarily complex. Understanding the relationships within the matrix is hard because data and knowledge are incomplete in many parts of the matrix; the impact of pushing one lever within the matrix on the rest of the apparatus is frequently unknown. In earlier sections, the discussions isolated some points in the matrix where mismatches and inefficiencies are more readily observable and are especially significant; it also identified some options for future reforms. But at each of these points, the various solutions, if implemented, create different arrays of winners and losers, which means that discussions of which ones to choose will be contested.

In other words, the overarching question lying at the heart of the matrix-and one that is typical of most substantial issues of governance and public policy - is who should pay for the costs of prevention,

259. This is one of the many important insights of Spencer Kimball, a preeminent and influential insurance law scholar during the last half of the twentieth century. See Spencer L. Kimball, Insurance and Public Policy (1960); Spencer L. Kimball, The Purpose of Insurance Regulation: A Preliminary Inquiry in the Theory of Insurance Law, 45 MinN. L. REv. 471, 524 (1961) ("Insurance is a small world that reflects the purposes of the larger world outside it."). For an explanation of the well-known description of politics as a system for the authoritative allocation of values, see DAVID Easton, A Framework for Political Analysis (1965); David Easton, A Systems Analysis of Political Life (1965). 
mitigation, and recovery with respect to hurricanes and other natural disasters. This is not so much a question of risk management and insurance as it is a question of allocation of values within the political system.

Explaining the political system as a collection of interactions through which a society's values are authoritatively allocated has an important shared element with traditional explanations of risk management activities and insurance mechanisms. A political system consists of processes and structures, with institutions of government constituting the most obvious examples of the latter. Authority (i.e., the authoritative allocation of values) assumes power, and allocation assumes scarcity (i.e., limited supplies of assets or resources). Although allocations in a political system need not be entirely distributive-for example, integrative solutions that create more value are often available, if the constraints of effort and time permit them to be found-they are inevitably partly distributive, which means there are winners and losers, and the losers provide cross-subsidies to the winners.

Insurance and other risk management strategies share this characteristic; they are essentially exercises in cross-subsidization. The essence of insurance is to pool, ex ante, assets from the many and redistribute them, ex post, to the unfortunate few who need them based on agreed standards from the time the pool was created. The unfortunate who suffer loss benefit from (i.e., are subsidized by) contributions made by the fortunate. Those excluded from the pool are on their own, and the unfortunate in that cohort bear commensurately greater burdens from loss-producing events insured by the pool.

The foregoing manner of cross-subsidization is desirable, but not all kinds of cross-subsidization are. If risk is not valued accurately, those who pay more in premiums than the value of their risk provide a cross-subsidy to those who pay less, and this kind of cross-subsidy is undesirable. Generally, policyholders expect that insurance will be priced close to the value of the risk transferred. Those who create or face low amounts of risk do not expect to provide subsidies to those who make choices to bear more risk. Similarly, those who make higher-risk choices, although they might prefer to pay less in premiums and might advocate that outcome, cannot reasonably expect those who make lower-risk choices to pay the larger costs associated with their higher-risk choices. ${ }^{260}$ Automobile insurance provides a

260. At a certain point, when the cost of measuring the difference between a higher-risk choice and a lower-risk choice exceeds the benefit in premium reduction that can be offered the lower-risk insured, the measurement and the distinction will not be made, and the higher-risk and lower-risk insureds will be pooled together. In other words, market settle toward an equilibrium in which insureds of different risk levels will be grouped within a single pool. For more discussion, see JERRY \& RICHMOND, supra note 66, at 14-16. 
good illustration: those who drive fewer miles, own less expensive cars that cost less to repair, and have a history of fewer accidents and traffic tickets do not expect to subsidize the insurance of those who have accidents more frequently in luxury vehicles that they operate more often. To translate the example to natural disaster risk, owners of less expensive homes located in areas with no hurricane risk (e.g., a homeowner in Green Bay, Wisconsin) do not expect premium pricing that causes them to subsidize those who own more expensive homes in higher-risk areas (e.g., an owner of beachfront property in Pensacola Beach, Florida).

Because there are cross-subsidies throughout the risk managementrecovery matrix, one way to frame a discussion about future risk management policy is to ask how these cross-subsidies should be designed. Our society has rejected on both economic and political grounds an answer that each individual and firm is on its own when dealing with natural disaster risk, so some cross-subsidy of disaster victims is certain to occur. The government plays an indispensable role in natural disaster recovery, and public resources will always be important elements of the matrix, so taxpayers generally will be a source of the cross-subsidy to disaster victims. But are there limits on these crosssubsidies? Should the taxpayer cross-subsidy be limited when an individual fails to purchase available flood insurance, or fails to invest to some extent in pre-loss mitigation? Likewise, it is impossible to imagine a scenario where insurance will not play a major role in preparing for natural disaster loss and in providing compensation for loss once it occurs. To the extent private insurance is part of the grand strategy, the cross-subsidies are internal to the risks transferred to and distributed within the pool of covered insureds. To the extent government resources are used to subsidize the purchase of premiums in the private market, backstop the coverage, or underwrite the risk, the taxpayers provide the cross-subsidy. In these situations, are there limits to taxpayer-provided cross-subsidies resulting from a need for fiscal restraint in the context of expanding federal budget deficits? Further, the challenges created by the nature of natural disaster risk-i.e., all the factors that make it a difficult risk ${ }^{261}$-render it impossible to imagine a scenario where government will not play a role in regulating and supporting the private market. But, again, the question is how much support at what cost, with the resulting cross-subsidies, is too much?

The last question posed is not unfamiliar territory. Our political system is well acquainted with lines of insurance where a social policy intervenes and recasts the undisturbed market's cross-subsidies. When insurance is viewed as being imbued with characteristics of a public good to which all should have access, the economic realities of those

261. See Jerry \& Roberts, supra note 150. 
who have less ability to pay for the insurance sometimes leads to a government-imposed, means-based premium structure or a public subsidy arrangement that enables lower-income, lower-wealth individuals to have access to the market. In other situations, the high costs of insurance are perceived to impair useful, publicly valuable economic activity by individuals and firms, causing government to intervene to cap liabilities or regulate the market to make insurance more accessible. When this happens, the cost of access is ultimately subsidized by someone other than the firms and businesses that receive the benefit of the access. Does protection from natural disaster risk rise to this level of public good such that these kinds of market reforms are appropriate? Thus far, the outcomes in the U.S. political process indicate that the answer is in the affirmative, as this is the premise behind the creation of the NFIP and underlies the country's willingness to invest enormous sums in ex post disaster relief assistance. But how far should this willingness extend, especially given the misfiring in the current NFIP apparatus and the rapidly increasing costs of natural disaster relief?

The enormous costs of hurricanes and other natural disasters lay these kinds of questions squarely before us. Finding good answers is difficult. For example, in a market where many property owners already choose not to insure hurricane risk, accurately pricing wind and flood risk in hurricane-prone areas will drive prices higher, which will cause some policyholders to leave the market and make the market less accessible to those with limited financial resources. Absent government intervention to ameliorate these effects, insurance purchases will decline, which will have two consequences: (1) more households will endure greater financial hardship; and (2) the burdens on ex post disaster relief programs will grow-assuming disaster relief continues to enjoy a high priority in the list of core government responsibilities.

Other intersections in the matrix raise similar questions. For example, who should pay for prevention and mitigation efforts? One point of view would place these costs on the owners of the properties and assets that receive the benefits of prevention and mitigation, but in many instances these costs are prohibitive. Yet failing to take these measures puts pressure on disaster relief, which is essentially a crosssubsidy provided by taxpayers. To relieve taxpayers from the burdens of paying for post-loss disaster relief-essentially a massive subsidy from the taxpaying public to victims of disasters-Congress could choose to shift the taxpayer subsidy to mitigation and prevention expenditures that reduce the burdens on post-disaster relief efforts. When assets important to national security are located in harm's way (i.e., the Houston petrochemical industry ${ }^{262}$ ), the case for public in- 
vestment in prevention and mitigation is stronger. But even here the argument is controversial: Should taxpayers subsidize prevention and mitigation efforts to benefit industries whose products-even if used willingly by consumers (many of whom resist conservation efforts that would reduce reliance on the products in question) - have contributed to the climate change that increases the catastrophic losses that necessitate the increased investment in mitigation? ${ }^{263}$

Yet another question with cross-subsidy implications involves whether prevention, mitigation, and relief efforts should occur primarily at the federal level or at the state and local levels of government. Just over half of all states currently have dedicated disaster relief funds, some of which contain no money, and some of the most exposed states (e.g., Florida) are among those without dedicated disaster relief funds. ${ }^{264}$ Although some argue-reminiscent of the federal-state relationship for disaster assistance of nearly 100 years ago- that disaster relief is primarily a local and state responsibility, the reality is that stressed state budgets are not capable of assuming the primary financial responsibility for either disaster relief or prevention and mitigation investments. ${ }^{265}$ Although the lack of state readiness may be one result of the assumption that the federal government is poised to provide disaster relief and to supplement it when needed, no small amount of irony exists in the fact that lax state and local regulation coupled with underinvestment in pre-loss disaster relief funds in some regions results in increased natural disaster losses. Yet to the extent the federal government assists state efforts, a cross-subsidy is created between taxpayers in states that do not face the hurricane risk and those in states that do. One point of view is that this cross-subsidy

counts-how-houston-dominates-the-oil-industry/\#6caa1a6a6107 [https://perma.cc/ CSZ7-5E8C].

263. This is the essence of the debate over a controversial proposal to build, largely at federal government expense, a $\$ 61$ billion network of concrete seawalls, earthen barriers, floating gates, and steel levees on the Texas Gulf Coast to protect the petrochemical industry and other assets along the Gulf. See Jonathan Hilburg, Texas Fast-Tracks Seawalls for Oil and Gas Infrastructure, Architects NewsPaper (Aug. 23, 2018), https://archpaper.com/2018/08/rebuild-texas-seawalls-oil-gas-infrastructure/ [https://perma.cc/P62K-MTD2]; Will Weissert, Big Oil Asks Government to Protect It From Climate Change, AP News (Aug. 22, 2018), https://apnews.com/4adc5a2a2e6b45 df953ebcba6b63d171 [https://perma.cc/RLW6-PMRE].

264. See Marshall, supra note 236.

265. See Cezary Podkul \& Heather Gillers, Why Are States So Strapped for Cash? There Are Two Big Reasons, Wall Sт. J. (Mar. 29, 2018, 1:52 PM), https://www.wsj .com/articles/why-are-states-so-strapped-for-cash-there-are-two-big-reasons-15222555 21 [https://perma.cc/4AJ7-LADP] (explaining that states are already facing challenges to maintain core services in the face of increasing costs of Medicaid and public-employee health and retirement costs). A foreseeable $\$ 200$ billion disaster event dwarfs the Florida budget ( $\$ 88.7$ billion FY2019 budget) and is roughly equivalent to the entire two-year budget in Texas ( $\$ 217$ billion for the 2018 and 2019 budgets). See Tex. Comptroller of Pub. Accounts, Certifying the 2018-2019 Texas State BUDGET, available at https://comptroller.texas.gov/about/media-center/infographics/ 2017/budget-certification/. 
should not be expanded in circumstances where leaders of at-risk states have decided to keep taxes low for the benefit of their residents in lieu of investing in substantial prevention and mitigation efforts. Seven states have no state income tax, but two of these-Texas and Florida-are prime targets for hurricane losses and thus are among states that are most likely to seek federal disaster relief. 266

At the end of this assessment, then, articulating an effective, coherent natural disaster risk management policy remains difficult, and answers to questions about how to best shape the various cross-subsidies remain elusive. Designing a proposal that will survive the political process intact is daunting. Perhaps, then, the most important lesson of the natural disaster risk management-recovery matrix can be summarized with economist Thomas Sowell's famous observation: "There are no solutions; there are only trade-offs." 267

266. Marshall, supra note 236. Texas and Florida ranked 34th and 43rd, respectively, in total state and local tax revenue per capita in 2015. See Rankings of State and Local Per Capita General Revenue, TAx PoL'y CTR. (Dec. 15, 2017), https://www.tax policycenter.org/statistics/rankings-state-and-local-capita-general-revenue [https://per ma.cc/9BYT-D7Q8]. These states, and others at the bottom end of tax collections per capita, may make claims on general federal revenues for direct subsidies for disaster relief.

267. Thomas Sowell, The Vision of the Anointed: Self Congratulations as a Basis for Social Policy 142 (1996). 